\title{
DE VLAAMSE WESTVAART EN DE ENGELSE REPRESAILLES OMSTREEKS 1378
}

\author{
door
}

\author{
Roger DEGRYSE
}

\section{DE VLAAMSE WESTVAART EN HE'T EINDE VAN HET FRANS- ENGELS BESTAND IN 1377}

Toen op 21 juni 1377 Edward III, koning van Engeland, stierf, na veertig jaar voordien de strijd, naderhand genoemd de Honderjarige Oorlog, tegen de Franse kroon te hebben ingezet, gebeurde dit op een zeer kritiek ogenblik, namelijk de beëindiging van het wapenbestand, dat sinds 1372 tussen beide partijen geheerst had ${ }^{1}$. De Engelsen, die in West-Frankrijk bijna al hun veroveringen hadden moeten prijsgeven, bleven er evenwel aan de kust in het bezit van een reeks belangrijke voorposten en steunpunten, waaronder de havens Bayonne, Bordeaux, Brest en Calais, benevens Ponthieu met de Sommemonding, waaraan zij in 1379 nog het door hen ontzette Cherbourg zouden weten toe te voegen. Het meermaals verlengde bestand verstreek echter op 24 juni 1377 en de nieuwe Engelse vorst, Richard II, was, als tienjarige, stellig niet in staat om onmiddellijk het beleid van zijn rijk over te nemen. Karel V, de Franse koning, die in de jaren, die het bestand voorafgingen, erin geslaagd was het grootste deel van zijn land te bevrijden, had dus geen tijd te verliezen, wilde hij van de voor hem gunstige omstandigheden gebruik maken om zijn werk te voltooien ${ }^{2}$.

Verbonden met de vorsten van Leon-Kastilië en Schotland en geholpen door de koning van Portugal, zette Karel V van Frankrijk einde juni zonder dralen opnieuw te land en op zee de strijd tegen de Engelsen in. De Franse pogingen om aan de zuidkust van Engeland te landen leverden wel enig succes op, maar bleven uiteindelijk toch zonder gevolg, omdat de invallende strijdkrachten er niet toe kwamen om er, naar het voorbeeld van de Engelsen op het vasteland, vaste steunpunten te verwerven ${ }^{3}$. Erger was het gesteld op zee, waar de opflakkering van de zeeoorlog en de kaapvaart de internationale koopvaardij, waaronder vooral de westvaart op La Rochelle en Bordeaux, ernstig in het gedrang brachten, wat in de eerste plaats voor Vlaanderen nadelig kon zijn. De westvaart was inderdaad voor de Vlamingen de belangrijkste uiting van de hun nog resterende

(1) Ch. de La Roncière, Histoire de la marine française, dl I, Parijs, 1909, blz. 51 en 54. - E. Varenbergh, Histoire des relations diplomatiques entre le comté de Flandre et l'Angleterre au moyen âge, Brussel, 1874, blz. 411-417.

(2) Ph. Contamine, La guerre de Cent Ans (Coll. "Que je sais?", n 1309), Parijs, 1968, blz. 64-66.

(3) Ch. de La Roncière, a.w., blz. 51-57. - De Engelse havenstad Rye werd op 29 juni 1377 door de Fransen ingenomen en geplunderd, maar daarna door hen opnieuw ontruimd. Ibidem, blz. 53-54. 
actieve handel ${ }^{4}$. In normale omstandigheden verlieten elk jaar in het najaar meerdere Vlaamse en vreemde vloten het Zwin voor het westen om het volgende voorjaar naar Vlaanderen terug te keren ${ }^{5}$. Ook kon het gebeuren dat alle Vlaamse schepen bij elkaar aansloten in één enkel konvooi, dat dan als ,westvloot" de tocht naar La Rochelle en Poitou heen en terug volbracht ${ }^{6}$.

Lodewijk van Male, graaf van Vlaanderen, die, alhoewel sinds 1369 familiaal met de Franse kroon verbonden, in het conflict tussen de koningen van Frankrijk en Engeland een neutrale koers volgde, blijkt in het begin van het jaar 1377, in het vooruitzicht van het verstrijken van het wapenbestand, reeds enkele maatregelen tot beveiliging van de ,westvloot" genomen te hebben. Zo belastte hij de schippers slechts in admiraalschap en vlootverband uit te zeilen en steeds bij elkaar te blijven zonder de vloot te verlaten. De twee door de schippers verkozen admiraals of vloothoofden, die in dat geval de leiding waarnamen, dienden voor de naleving van deze ordonnantie in te staan. $\mathrm{Zij}$ moesten bij de terugkeer van de Vlaamse vloot in het Zwin aan de waterbaljuw aldaar de naam opgeven van de schippers, die in gebreke gebleven waren ${ }^{7}$. Nog vóór het midden

(4) De vijf richtingen van de Vlaamse actieve handel tot omstreeks 1300 waren die over de zee, respectievelijk naar Engeland, de Rijn, de Noordzee- en Oostzeekusten van Duitsland en de Atlantische kusten van Frankrijk en Spanje, en de richting over land naar Champagne en N.-Italië. Alleen de richting naar de Atlantische kusten van Frankrijk en Spanje zou na 1300 gebleven zijn, terwijl de vier andere uitingen van actieve handel geleidelijk in verval zouden geraakt zijn en zelfs teniet gegaan. H. Van Werveke, Brugge en Antwerpen, Acbt eeuwen Vlaamscbe bandel (Uitgave van het Willemsfonds, nr 177), Gent, 1941, blz. 28. Kaartje, blz. 31. Deze opvatting wordt heden niet meer zo strikt aanvaard, aangezien men aanneemt dat de verschillende richtingen over zee tot in de 16de eeuw zouden zijn blijven voortbestaan. Overigens bleef de richting naar Spanje zich tot in de 18de eeuw handhaven. Dr. W. Brulez, Brugge en Antwerpen, een tegenstelling? Tijdschrift voor Geschiedenis, 83ste jg., afl. 1, 1970, blz. 15-37. Daarin bewijst de auteur dat de beide grote havens elkaar, inzake actieve en passieve handel, eerder hebben aangevuld, in de plaats van elkaar te hebben in de weg gestaan, zodat er van een opvolging van de eerste haven door de tweede geen sprake geweest kan zijn.

(5) Jan Craeybeckx, Un grand commerce d'importation. Les vins de France aux anciens Pays-Bas (XIIIe-XVIe siècles), Parijs, 1958, blz. 118-119. - Van november 1419 tot januari 1420 wordt er in de gelijktijdige bronnen melding gemaakt van de vorming te Sluis achtereenvolgens van drie vloten met bestemming naar La Rochelle, Ibidem, blz. 119.

(6) De term ",westvlote van Vlaendren" treffen we voor het eerst aan in de rekening van Jan Lennoot, "rewaert" van Sluis en waterbaljuw van Mude, over het ambtstermijn 1 dec. 1382 - 4 mei 1383. Froissart's cronijke van Vlaendren, vertaling door Gerijt Potter van der Loo, uitgave N. De Pauw, Gent, 1898-1909, dl II, blz. 134.

(7) „Item, zo calengierde de balliu vorseid de scepen, die laetst quamen van westen, van dat zij te broken souden hebben $\mathrm{d}$ ordenanche, die ghemaect was bi minen gheduchten heere van Vlaendren, van te gadre te blivene metten vlote, waer of de bailliu maende de amiraelz van der vlote bi haren eeden, dat zij hem gheven soude degone, die der of in ghebreke waren, waerup zij verandworden dat zij claerlike niet en wisten offer yemen in ghebreke of ware. Ende omme dat eene grote vlote was ende der yemen in ghebreke of mochte zijn, so ghaven zij den bailliu vorseid te mijns gheduchts heeren bouf $240 \mathrm{lb."}$. Brussel, Alg. Rijksarchief, Rekenkamer van Vlaanderen en Brabant, rolrekening $\mathrm{nr} 1502$ (of 1503), rekening van Jan Lennoot, waterbaljuw van Mude, over het ambtstermijn 11 mei - 20 sept. 1377. 
van hetzelfde jaar zou de graaf de beide verkozen admiraals, die zich aan zijn instrukties hadden willen onttrekken, door één kapitein vervangen. Deze grafelijke officier, die weldra door de Engelsen admiraal van Vlaanderen betiteld zou worden, kreeg als enig vloothoofd het bevel over de Vlaamse ,westvloot" 8. We mogen dan ook aanvaarden, dat Matthys Claissone, die alsdan in deze hoedanigheid vernoemd wordt ${ }^{9}$, de eerste admiraal van Vlaanderen is geweest ${ }^{10}$. Voortaan zouden de schippers, die, na het vertrek uit Sluis of uit la Rochelle, zonder toelating van de grafelijke kapitein, de vloot verlieten, bij hun terugkeer in het Zwin door de waterbaljuw aldaar gerechtelijk vervolgd worden ${ }^{11}$.

Het is duidelijk waarom de graaf al deze maatregelen had doen treffen. De represailles, waaraan de schippers bij het verlaten van Sluis of op hun terugkeer naar Vlaanderen bloot stonden, waren zo toegenomen, dat men het ergste begon te vrezen. Eenmaal het Frans-Engels bestand verstreken, werd deze vrees snel bevestigd. De Franse aanvallen lokten immers, sneller dan verwacht, een Engelse reactie uit. De Engelsen stonden inderdaad, niettegenstaande al hun tegenslagen, niet volledig onvoorbereid voor de nakende strijd. Nog in 1377 was in de belangrijke strategische plaats en haven Calais, waar zich sinds 1363 de Engelse wolstapel bevond, als gouverneur een nieuwe kapitein aangesteld geworden, namelijk Hugo Calverley. Deze liet reeds in oktober van zich spreken, toen hij onverwachts een spectaculaire raid op het nabijgelegen Boulogne ondernam en er de aldaar liggende schepen in brand stak. Kort daarop slaagde een Engels smaldeel, onder de leiding van Thomas Percy, er in een Spaanse vloot, die, na opont-

(8) Het is niet zeer duidelijk hoe en op welk ogenblik deze vervanging plaats gevonden heeft. Het is mogelijk dat dit gedurende de terugkeer van de westvloot omstreeks mei 1377 moet gebeurd zijn, terwijl de beide door de schippers gekozen admiraals voor het laatst het bevel voerden. In dezelfde rekening van de waterbaljuw van Mude is er immers sprake van de terugkeer zowel van de twee admiraals, als van de kapitein. Laatstgenoemde kwam terug uit Bretagne: „Item, ghecalengiert winen van Gasscoengen van eenen scepe, dat brac in Bretaengen, de welke winen de capitein van der vlote van Vlaendren dede visschen of zij hadden alle verloren ghebleven. Ende de welke winen in $t Z_{w i n}$ quamen. Ende mids dat se de vorseide capitein behouden hadde ende hi was in den name van minen gheduchten heere van Vlaendren. So heift de bailliu vorseid huut gracien de vorseide winen telivereert den cooplieden, dien zij toe behoorden ende der of ontfaen $36 \mathrm{lb."}$. Ibidem, rekening van Jan Lennoot over het ambtstermijn 11 mei - 20 sept. 1377.

(9) Bijlagen II (nrs 20 en 25) en X.

(10) In een vroeger artikel schreven we dat we de naam van de eerste admiraal van Vlaanderen niet kenden. R. Degryse, Uit de geschiedenis van onze zeemacht, de oorsprong van de admiraliteit van Vlaanderen onder Lodewijk van Male, in Bijdr. Gesch. der Ned., dl XIV, 1959, afl. 3, blz. 177-196. Zie blz. 183-184.

(11) „Item, ghecalengiert Pieter den Stoker, meester van eenen cleenen scepe van der Sluus, van dat hi zeilde uuter vlote, die laetst westwaerd zeilde, boven den ordinanche, die der up gheordineert was bi minen gheduchten heere van Vlaendren ende boven den beveelne van den capitein van der vlote, pais omme $120 \mathrm{lb} . "$. Brussel, Alg. Rijksarchief, Rekenkamer van V1. en Brab., rolrekening nr 1506, rekening van Jan Lennoot, waterbaljuw van Mude, over het ambtstermijn 11 jan. 10 mei - 20 september 1378. Volgen dan nog twee soortgelijke beboetingen.

„Item, ghecalengiert Lamsin Horneweder, van dat hi zeilde uuter vlote, sonder orlof van den capitein van der vlote ende sine ghesellen, pais omme $60 \mathrm{lb."}$.' Ibidem, nr 1507, rekening van Jan Lennoot, waterbaljuw van Mude, over het ambtstermijn 10 mei - 20 september 1378 . Volgen dan nog twee soortgelijke beboetingen. 
houd voor een storm, Sluis uitgevaren was, te onderscheppen en van de zowat vijftig vaartuigen, die zij telde, er een twintigtal te overweldigen ${ }^{12}$.

Niettegenstaande de hervatting van de krijgsverrichtingen tussen de Fransen en de Engelsen, blijkt Matthys Claissone in het najaar 1377 nog zonder grote moeilijkheden de Vlaamse vloot westwaarts te hebben kunnen loodsen ${ }^{13}$. Minder vreedzaam zou het er tijdens het voorjaar 1378 voor de eerste retourvloot aan toe gaan. De Engelsen wachtten inderdaad tot na de winter om het eigenlijk tegenoffensief tegen de Fransen in te zetten. Een vloot van zowat vijftig schepen uit Plymouth ging vóór $\mathrm{La}$ Rochelle en de kusten van Poitou kruisen, terwijl een andere formatie, aangevoerd door de beide Engelse admiraals, Richard Arundell en William Salisbury, de kusten van Normandië en meer bepaald de Seinemonding kwam bedreigen in afwachting van daarna Cherbourg te ontzetten en te bezetten ${ }^{14}$. Er deden zich dan ook enkele wrijvingen voor, waarbij Matthys Claissone en zijn gezellen zich zouden hebben laten gelden.

Een van de incidenten, die zich in het voorjaar 1378 voordeden en waarbij de kapitein van de Vlaamse vloot betrokken was, vormt een typisch voorbeeld van de moeilijke situatie van de Vlamingen te midden van de op zee strijdende partijen. In een klacht stelden de lieden van Plymouth inderdaad de overweldiging door Matthys Claissone en zijn gezellen van een door hen gekaapt Spaans schip en van een kraaier aan de kaak met de bezwarende omstandigheid dat de bemanning van laatstgenoemd vaartuig door de Vlamingen zou zijn uitgemoord. De kapitein van de Vlaamse ",westvloot" antwoordde naderhand op deze aantijgingen met een verweerschrift, waarin hij uiteenzette wat volgens hem en zijn gezellen de ware toedracht van de feiten geweest was. Bij de Vlaamse vloot zou zich een Spaans vaartuig gevoegd hebben, dat op een bepaald ogenblik een aanval van Engelse kapers uit Plymouth en Dartmouth te verduren kreeg, maar van zich af wist te bijten, zo zelfs dat de aanvallers een kraaier in de steek moesten laten. In dat vaartuig herkenden de Vlamingen evenwel een vroeger door de Engelsen gekaapt schip toebehorend aan Bruggelingen. Matthys Claissone en zijn gezellen zouden zich dan ook gehaast hebben met hun bootjes naar de kraaier te varen om het schip van de Spanjaarden afhandig te maken. Voor het overige beweerden zij zich bij de botsing tussen de Engelse kapers en de Spanjaarden volledig neutraal gedragen te hebben, wat niet belette, dat naderhand beide partijen tegen hen klacht indienen zouden en zelfs vervolging inspannen ${ }^{15}$. Kort na dit incident zouden Matthys Claissone en zijn gezellen zich in een Bretoense haven aan een tweede wandaad, namelijk het kapen van een Engelse kogge, geladen met wijn uit Gascogne, schuldig gemaakt hebben ${ }^{16}$. Wellicht was het als gevolg van deze voorvallen, dat de Engelsen zich wreekten door tijdens de terugkeer van dezelfde ,westvloot" naar het Zwin, zeven Vlaam-

(12) Ch. de La Roncière, a.w., dl I, blz. 57.

(13) Zie voetnoot 11 , eerste item.

(14) Ch. de La Roncière, a.w., dl I, blz. 60-61.

(15) Bijlagen II ( $\mathrm{nr}$ 25) en X. - De door de Engelsen geroofde kraaier behoorde aan Jehan de Tournay, een Bruggeling.

(16) Bijlage II, nr 20. 
se schepen, geladen met wijn, naar Plymouth op te brengen of aldaar bij hun aankomst aan de ketting te doen leggen ${ }^{17}$.

Ongetwijfeld waren het al deze feiten, benevens de blokkade, waaraan het Zwin voortaan blootstond, die Lodewijk van Male in datzelfde voorjaar van 1378 er toe brachten enkele nieuwe matregelen voor de beveiliging van de koopvaardij op Vlaanderen te treffen. De graaf mobiliseerde inderdaad een zeker aantal lieden uit de kleine steden van het Brugse Vrije om ze, onder de leiding van zijn admiraal, in zee vóór de kust als ,uitleggers" te laten patrouilleren en aldus de "stroom" of zeeroute aldaar te doen bewaken. Deze door de vorst aangestelde admiraal was ongetwijfeld Matthys Claissone, de kapitein van de ,westvloot", die zich nu voor het eerst een ambtelijke titel toegekend zag worden. Wegens het verzet van de kleine steden uit het Brugse Vrije, die in de levering van manschappen voor de grafelijke marine een precedent zagen, was het uitsturen van ,uitleggers" in 1378 slechts een experiment ${ }^{18}$. Een tweede maatregel schijnt meer effect gehad te hebben. Geen enkel schip mocht voortaan nog op eigen initiatief en zonder toelating van de waterbaljuw het Zwin uitzeilen, tot zolang die officier van hogerhand geen ander bevel doorgegeven had. Dat aan deze ordonnantie streng de hand gehouden werd, blijkt voldoende uit de beboetingen, die door de waterbaljuw aan de overtreders ervan werden opgelegd ${ }^{19}$. Dit alles geeft ongeveer de toestand op zee en in de Vlaamse westvaart weer, op het ogenblik dat in mei 1378 de besprekingen tussen de commissarissen van de Engelse koning en die van de graaf van Vlaanderen werden ingezet.

Aan de klachten en eisen van Vlamingen en Engelsen werden door de vertegenwoordigers van de beide partijen verschillende conferenties ge-

(17) Ibidem, nrs 7 tot 13: zeven klachten, waarin evenwel slechts van zes vaartuigen sprake is. Het zevende schip kan dit geweest zijn behorend aan Adriaen Tant uit Sluis, maar dit was geladen met gekaakte en gerookte haring en op weg naar La Rochelle. Zie bijlage III, nr. 3.

(18) Deze maatregel lokt vanwege de kleine steden van het Brugse Vrije protest uit, zodat de graaf zich gedwongen zag hen een brief van non-prejudicie te verlenen: „, dat als bi ons ende onsen lande ghemeenlike overeenghedraghen es te zendene ende te legghene ter zee zeker quantiteit van lieden ute onsen lande om onsen stroom te bevrijene, zo dat alle goede cooplieden vrij moghen varen ende keren met haren coopmanscepen onse land versoukende... Ende een deel van desen lieden derof ghenomen zijn uten smalen steden van den Bruxschen Vrijen, de welke wij ute onsen herlicheit ghenomen hebben $t$ ons waert ende ghedaen wezen bi onsen amiral, die wij dertoe ghestelt ende gheordeneert hebben...". E. Vanden Bussche, Inv. des arch. de l'Etat à Bruges, 1re section: Franc de Bruges. Brugge, 1881-1884, 2 delen. Deel I, chartes, blz. 293, nr 634. Stuk van 24 mei 1378.

(19) „Item, ghecalengiert Boudine van Steenberghe, van dat mijn gheduchte heere van Vlaendren bevolen hadde, dat niemen zeilen zoude buten Zwene. Ende bovendien dat hem de bailliu dede bevelen up sijn lijf ende goed, dat hi nieuwer seilen soude, so seilde hi, pais omme 120 lb.". Brussel, Alg. Rijksarchief, Rekenkamer van V1. en Brab., Rolrekening nr 1507, rekening van Jan Lennoot, baljuw van het water te Mude, over het ambtstermijn 10 mei - 20 sept. 1378.

„Item, ghecalengiert Heinric f. Domaes, van dat hi zeilde buten Zwene, bovendien dat de bailliu verboden hadde van mijns gheduchts heeren weghe van Vlaendren, dat gheene scepen zeilen zouden buten Zwene eer hi ander bevel hadde van minen gheduchten heere vornomt. Ende daetboven zeilde hi, pais omme $60 \mathrm{lb}$.". Ibidem, nr 1509, rekening van Jan Lennoot, waterbaljuw van Mude, over het ambtstermijn 20 sept. $1378-10$ jan. 1379. 
wijd, waarvan we de juiste inhoud niet steeds kennen. Zo greep een eerste samenkomst plaats in de loop van de maand mei 1378 te Brugge, waar heel waarschijnlijk de modaliteiten en de procedure van de te voeren onderhandelingen geregeld werden ${ }^{20}$. De volgende vergadering, die in het begin van de maand juli te Calais gehouden werd, hield zich inderdaad bezig met de bespreking van de langs beide kanten ingediende klachten nopens de gepleegde represailles. Voor sommige gevallen kon een regeling tot schadeloosstelling worden getroffen of in het vooruitzicht gesteld en voor andere niet of werd een onderzoek naar de waarachtigheid ervan bevolen ${ }^{21}$. De nog hangende kwesties zouden dan opnieuw besproken worden op een conferentie te Grevelinge op 25 november, waarover we evenwel geen bijzonderheden gevonden hebben ${ }^{22}$. Ondertussen blijken nieuwe moeilijkheden te zijn gerezen als gevolg van het uitblijven van sommige beloofde regelingen en hadden zich nog eens represailles voorgedaan. In verband daarmee werd te Brugge op 26 mei 1379 andermaal een vergadering belegd, waar vooral de Engelse klachten ${ }^{23}$ en de vernieuwde eisen van de lieden van Sluis aan bod kwamen ${ }^{24}$. Niettegenstaande in naam van de Engelse koning meermaals druk uitgeoefend geworden was op degenen, die zich, als kaper of officier in koninklijke dienst, aan represailles op Vlamingen schuldig gemaakt hadden, blijkt er inderdaad van het herstel van sommige schadeposten weinig of niets in huis te zijn gekomen ${ }^{25}$.

Ontevreden waren vooral zekere burgers van Brugge en Sluis, waaronder verschillende, die het jaar voordien reeds klacht hadden neergelegd en nog steeds niet waren vergoed geworden voor het door hen geleden verlies aan haring of graan op de zeeweg tussen het Zwin en de monding van de Somme, die toen Engels gebied was, of omgekeerd ${ }^{26}$. Het waren vooral

(20) Bijlage I.

(21) Op elke klacht volgt inderdaad een antwoord in de zin van de getroffen regeling. Zie bijlage II. - Een van de zes Engelse koninklijke commissarissen was Hugo Calverley.

(22) Ibidem, nr de nrs 13 en 27.

(23) Bijlage IV.

(24) De klachtenlijst is niet gedateerd, maar daar er in het stuk ook gewag gemaakt wordt van Engelse represailles van ongeveer een jaar voordien, is het duidelijk dat met de "traitiet" te Brugge de conferentie van 26 mei 1379 bedoeld werd. Zie bijlage III.

(25) Bijlage III, nr 1.

(26) „Gravem quaerimoniam mercatorem villarum de Lescluse et Brugges in Flandria recepimus, continentem quod licet ipsi diverses naves cum allece, frumento et aliis mercandisis et bonis suis propriis apud Somme carcari fecissent, ad easdem naves et mercandisas usque le Swyn in Flandria, prout eis licuit, ducendum, dicta tamen naves et mercandisae, supra mare versus dictas partes de Swyn... per homines nostros ligeos dictorum quinque portuum vi et armis captae et infra libertatem portuum praedictorum ductae et ibidem injuste detentae... unde nobis supplicarunt, ut eis super restitutione mercandisarum et bonorum suorum praedicatorum justiciam fieri jubere dignaremur..." E. Varenbergh, a.w., blz. 460, bewijsstuk nr XIV. Brief van Richard II, koning van Engeland, van 20 maart (1380) en gericht aan de kapitein van het kasteel te Dover en de lieden van de Cinque Ports. Oorkonde berustend in het British Record Office te Londen, zonder jaartal. - Van kaakharing bestemd voor de Sommestreek is et inderdaad sprake in een van de klachten uitgaande van de lieden van Sluis. Zie bijlage III, nt. 6. - In de andere Vlaamse klachten komen er een paar gevallen van confiscatie van graan door de Engelsen voor. Zie bijlage II, nrs 3 en 6 . 
de lieden van de Cinque Ports of de havensteden Sandwich, Dover, Hythe, Romney en Hastings, die op de koninklijke aanmaningen niet steeds met de nodige haast ingingen ${ }^{27}$. Te Calais deinsden de Engelse kapers er zelfs niet voor terug een Bruggeling, die aldaar, als volmachtdrager in naam van een benadeligde koopman uit Sluis, genoegdoening kwam eisen, in de gevangenis te werpen om hem aldus te dwingen te verklaren, dat de gearresteerde goederen vijandelijk bezit waren ${ }^{28}$. Zulke intimidaties, die somtijds zelfs met doodsbedreiging gepaard gingen ${ }^{29}$, waren natuurlijk niet van aard om de oplossing van de nog hangende kwesties te vergemakkelijken. In hun klachten wezen de Vlamingen dan ook terecht op de waarborgen en tegemoetkomingen, die hen vanwege de koning van Engeland en de graaf van Vlaanderen door tractaat verleend waren geworden, namelijk het recht zich vrij en ongehinderd, maar voorzien van de nodige bewijzen van borgtocht hen door hun vorst of hun gemeente afgeleverd, te midden van de Engelsen te mogen begeven, ophouden en verplaatsen ${ }^{30}$. In vele gevallen van represaille waren deze borgstellingen door de Engelse kapers volledig genegegeerd geworden ${ }^{31}$. Anders was het natuurlijk gesteld met de Vlaamse schippers en kooplui, die varend in opdracht van Engelsen, zonder de toelating van hun opdrachtgever, de Engelse vloot in de steek gelaten hadden om naar de Vlaamse ",westvloot" of een Vlaamse haven over te lopen en zich daarbij aan roof schuldig te maken. Het spreekt vanzelf, dat in dergelijk geval de benadeelde Engelse handelaars in hun klaagbrieven op hun beurt schadevergoeding voor het geleden verlies mochten eisen ${ }^{32}$. Dat deden zij bovendien ook voor een paar ladingen lakens, die, in het najaar van 1377 of het daaropvolgend voorjaar, te Sluis, in of buiten de haven, door de waterbaljuw gearresteerd werden, niettegenstaande de schippers, die dit goed vervoerden, aldaar als gevolg van storm terecht gekomen waren en er dus niet wetens en willens de reglementen hadden overtreden ${ }^{33}$.

De Vlaamse westvaart blijkt in 1379 en volgende jaren, ondanks de Engelse en Franse represailles, steeds op de gebruikelijke wijze plaatsgevonden te hebben. Alhoewel we over hem niets meer vernemen, tenzij in 1382, fungeerde als kapitein of "amiral van der Vlaemscher vlote" toen nog steeds Matthys Caissone. In dat jaar rebelleerden tegen hem in de Engelse wateren te "Cresdune”, d.i. in de Downs, enkele schippers, die

(27) Reeds op 4 februari 1378 had de Engelse koning zich schriftelijk tot de kapitein van het kasteel te Dover en de lieden van de Cinque Ports gericht om hen aan te manen in te gaan op het verzoek van benadeelde Vlaamse schippers schadeloos te worden gesteld voor het verlies aan vrachtgeld, wegens schade geleden door Engelse represailles en het optreden van kapers, onder de leiding van ridder Thomas Percy. E. Varenbergh, a.w., blz. 420 en 422, evenals blz. 457, bewijsstuk nr XI. De kapitein van het kasteel te Dover, aan wie Richard II opdracht gaf in te grijpen, was Edmund, graaf van Kent en "custos" van de Cinque Ports. Zie ook voetnoot 26 hierboven.

(28) Bijlage III, nr 5.

(29) Bijlage III, nr 1.

(30) Ibidem.

(31) Bijlage III, nr 7.

(32) Bijlage II, nr 19

(33) Bijlage II, nts 26 en 27. 
naar de Engelsen, toenmaals bondgenoten van de opstandige Gentenaars, hadden willen overlopen en daarom bij hun aankomst in het Zwin door de waterbaljuw bestraft werden ${ }^{34}$. De door Lodewijk van Male uitgevaardigde verordeningen waren toen nog steeds van kracht. In 1383 zou Matthys Claissone, als admiraal van Vlaanderen en kapitein van de ,westvloot", door ridder Jan Buuc, een ingezetene uit Sluis, worden opgevolgd ${ }^{35}$.

\section{DE MARITIEME EN COMMERCIELE ASPECTEN VAN DE WEST- VAART OMSTREEKS 1378}

De twee voornaamste lijsten van klachten, die we onderzoeken, vormden het voorwerp van onderhandelingen, die gevoerd werden respectievelijk op de conferenties gehouden te Calais op 10 juli 1378 en te Brugge op 26 mei 1379. Daarnaast beschikken we nog over een viertal verweerschriften, uitgaande van de admiraal van Vlaanderen en van Vlaamse schippers, die door de Engelsen van zeeroverij beschuldigd geworden waren ${ }^{36}$. Het document met de inhoud van de bespreking van de Vlaamse klachten op de conferentie van Calais heeft het ook over de Engelse represailles op de Vlamingen gepleegd gedurende de laatste twee jaren, d.i. kort voór of kort na de beëindiging van het Frans-Engels wapenbestand op 24 juli 1377, evenals over de latere vergeldingen door Vlamingen en Engelsen op elkaar gepleegd. Indien we in het eerste document lieden van over gans de Vlaamse kust aan bod zien komen, dan is dit niet zo in het tweede stuk, waarin uitsluitend klachten uitgaande van de benadeelde burgets van Sluis staan. Sommige onder deze laatste klachten vinden we trouwens reeds in het verslag van de besprekingen te Calais aangehaald. Daardoor verkrijgen we enigszins aanvullende inlichtingen. Bovendien verschaffen de Vlaamse verweerschriften ons bijkomende bijzonderheden en rechtzettingen, zodat we de Engelse en Vlaamse voorstellingen van de feiten met elkaar kunnen confronteren. Ten slotte blijkt uit al deze getuigenissen, dat er naast de westvaart nog andere richtingen bestonden, waarin de Vlaamse actieve handel zich steeds liet gelden, namelijk de koopvaardij op Schonen ${ }^{37}$ en

(34) „In t eerste, ghecalengiert Jan de Brest van Rocheelle ende zijn goet, omdat hi rebel was ende hem stelde jeghen Matthijs fs.Clais, amirael van der Vlaemscher vlote in Cresdune, pais ghemaect om 72 Ib.". Brussel, Alg. Rijksarchief, Rekenkamer van VI. en Brab., nr 1.516. Rekening van Jan Walkier, waterbaljuw van Muide, over het ambtstermijn 13 jan. - 5 mei 1382. Gepubliceerd door N. de Pauw, in Froissart's cronijke van Vlaendren, vertaling door Gerijt Potter van der Loo, a.w., dl II, blz. 118. Op deze "calenge" volgen in de rekening nog twee soortgelijke beboetingen opgelegd waarschijnlijk aan Vlaamse schippers. - Cresdune lag vóór de Engelse kust aan de ingang van het Nauw van Calais.

(35) R. Degryse. Uit de geschiedenis van onze zeemacht, de oorsprong van de admiraliteit van Vlaanderen onder Lodewijk van Male, a.w., blz. 185 en volgende.

(36) Rijsel, Arch. dép. du Nord, B 515/18.288 (Calais, 10 juli 1378), B 515 / 18.286 (1379, klachtenlijst van de lieden van Sluis) en B 515/18.778 bis (Vlaamsche verweerschriften en antwoorden op de Engelse aantijgingen). Zie bijlagen II, III, IV, V, VII, IX en X.

(37) Een korver uit Oostende, geladen met zout, bestemd voor Schonen, werd na 
de vrachtvaart op Engeland ${ }^{38}$ en Ierland ${ }^{39}$. In de betreffende stukken worden zelfs een paar gevallen van wandaden op of door Vlaamse vissers op zee gepleegd vermeld ${ }^{40}$.

De gegevens, die we hebben over de Engelse represailles op zee of in de gebieden staande onder Engelse heerschappij lichten ons in over enkele van de meest typische aspecten van de Vlaamse westvaart. Het waren vooral ingezetenen van Sluis, Damme en Brugge, die, als makelaars, reders, schippers of kooplui, bij deze koopvaardij betrokken waren, zonder daarom steeds zelf aan de reizen deel te nemen. De meeste schippers, die met hun vaartuig voor eigen rekening of als geassocieerde in dienst van een koopman aan vrachtvaart deden, waren lieden van Sluis, toenmaals de Zwinhaven bij uitstek, maar daarnaast treffen we ook stuurlui uit Nieuwpoort, Duinkerke, Oostende, Biervliet, Terneuzen en Hulst met hetzelfde beroep aan. Sommige schippers zonder eigen vaartuig voeren in opdracht van Vlaamse reders ${ }^{41}$. Dezen traden op hun beurt soms voor rekening van Engelse kooplui op.

Voor het vervoer van de meest uiteenlopende producten, als haring, wijn, zuidvruchten, zout, as, lood, smeer, wol en lakens, verpakt in allerlei soorten verpakkingen als vaten, manden, zakken en balen, gebruikte men vanzelfsprekend scheepstypes, die daarvoor geschikt waren. Zo wordt vooral van de kogge en de "nef" gewag gemaakt, maar daarnaast ook van de baardse, de hulk, de kraaier en zelfs de korver. Van de zes koggen, waarvan in de twee klachtenlijsten sprake is, behoorden er niet minder dan vier aan burgers van Sluis. Daaronder bevond zich ook de kleine kogge van de stuurman-deelgenoot Clais Heins ${ }^{42}$. Beide teksten vermelden voorts een tiental ,nefs", waaronder ook de schepen, die met wijn geladen en van La Rochelle terugkerend, door de Engelsen naar Plymouth opgebracht of aldaar gearresteerd en beroofd werden ${ }^{43}$. Beide scheepstypes, kogge en , nef", kwamen toen blijkbaar, wegens hun grote geschiktheid voor het vervoer van tonnen kaakharing of vaten wijn in de Vlaamse westvaart het meest voor. Ook de andere aangehaalde types van zeeschepen konden voor der-

haar vertrek uit Sluis op zee door drie Engelse baardsen, respectievelijk uit Londen, York en Kings Lynn aangevallen en haar bemanning, bestaande uit de stuurman, achttien vennoten en twee scheepsjongens, uitgemoord. Bijlage II, nr 17.

(38) Vlaamse schippers vaarden immers op Engeland, Calais, de Sommemonding en Bordeaux voor rekening van Engelse kooplui, terwijl Vlaamse vissers tijdens het haringseizoen nog steeds de Engelse Noordzeehavens aandeden. Dit blijkt uit de Engelse klachten en de Vlaamse verweerschriften. Zie de voetnoten 36 en 37 , evenals bijlage VIII.

(39) In Ierland werd Dublin (,Develinghe”) aangedaan. Bijlage II, nr 15.

(40) Bijlagen II (nrs 17 en 22) en VIII.

(41) Bijlage II, nts $1,2,6$ en 8.

(42) Voor de koggen, zie de bijlagen II ( $\mathrm{nr}$ 2), III (nrs 1,5 en 9) en VI, en voor de korver, bijlage II, nr 17, en voetnoot 37 .

(43) De term ,nef" sloeg niet steeds op een bepaald scheepstype, maar betekende soms eenvoudig schip. Zo werd de kogge, waarvan Ghijs Cudel uit Sluis de schipper en Jaque Crakebeen een van de eigenaars was, ook "neif" genoemd. Onder de "7 neifs, qui furent prises a Playnemude", bevonden zich ook de kleine kogge en de hulk, waarvan respectievelijk Clais Heins uit Sluis en Clais Porre uit Dordrecht de schippers waren. Bijlagen II (nts 7 tot 13), III ( $\mathrm{nr} 11$ ), V en VI. - Zie ook voetnoot 17 . 
gelijk transport ingezet worden. Het juiste draagvermogen van al deze vaartuigen wordt ons in de documenten niet meegedeeld. Wel vernemen we uit deze stukken zeer dikwijls de namen van de schipper, de eigenaars en de geassocieerde kooplui met daarnaast de cijfers van de geleden verliezen, uitgedrukt door de hoeveelheid goederen of de waarde ervan in speciën. Daardoor krijgen we wel enig idee van de tonnenmaat van de desbetreffende schepen, evenals van de verdeling van het eigendomsrecht per vaartuig. Zo vervoerde de ,nef" van Jehan de Mol uit Biervliet voor rekening van die schipper zelf en van verschillende kooplui een lading bestaande in het totaal uit 153 vaten wijn, toen de Engelsen te Plymouth er de hand op legden ${ }^{44}$. De kogge van Adriaan Tant uit Sluis transporteerde 32 last 3 tonnen of in het totaal 387 tonnen Schonense kaakharing, benevens een vat olie, op het ogenblik dat een Engelse kaper haar praaide en naar Calais opbracht ${ }^{45}$. Indien Jehan de $\mathrm{Mol}$ en ook Adriaan Tant elk als schipper of reder-eigenaar van een vaartuig waren, dan was dat in andere gevallen anders. Aldus bezat Clais Heins uit Sluis, die in de baai van Bourgneuf in duistere omstandigheden doodgestoken werd, slechts een zesde in de kleine kogge, waarvan hij de schipper was, benevens een zesde in de lading ervan bestaande uit 500 "delen" zout ${ }^{46}$. Henri Bast, een bekende waard uit Sluis, was in het bezit van een vierde deel in een hulk en de lading ervan ${ }^{47}$ en Jacob Hogheneuze, koopman uit Brugge, had eveneens een vierde in de kogge, genaamd de "Christoffel", uit de Zwinhaven ${ }^{48}$. Op te merken is dat de enige baardse, waarvan in de klaagbrief van de Sluizenaars sprake is, aan de graaf toebehoorde. De schipper ervan heette Romboud Arnoudzuene. Het vaartuig zelf was omstreeks 11 november 1378 door de gebroeders Jehan en Riquaerd van Cleyem uit Sluis met 19 last gerookte haring, bestemd voor Engeland, bevracht geworden ${ }^{49}$.

Het voornaamste product, dat de Vlaamse kooplui westwaarts en vooral naar de Sommemonding, Normandië, La Rochelle en Bordeaux verscheepten, was haring, meer bepaald gekaakte en gerookte. Op de terugkeer naar Vlaanderen brachten de schippers, in opdracht van degenen voor wie ze voeren, vooral wijn uit Gascogne of Poitou, zout uit de baai van Bourgneuf, graan uit Ponthieu en wol uit Calais mee. Ze deden dus ook aan vrachtvaart voor Engelse kooplui. Het gebeurde zelfs dat ze voor rekening van hun opdrachtgevers Spaanse of Portugese havens bezochten en er een

(44) Bijlage II, nrs 7 (onder „envoia” moet ongetwijfeld „chargea” begrepen worden) en 8 . We beschouwen inderdaad de beide klachten als betrekking hebbende op één en hetzelfde vaartuig.

(45) Bijlage III, nr 5. - De kaper stond in dienst van Hugo Calverley.

(46) „Item, ghecalengiert $t$ sestendeel van eenen cleenen cogghe ende $t$ sestendeel van 500 zouts toebehorende eenen Clais Heins, die bastaerd was ende doot ghesteken es in de Baye, dewelke deelle de bailliu vercocht heift ende daer of ontfaen 102 lb. 16 s. (par.)". Brussel, Alg. Rijksarch., Rekenkamer van Vl. en Brab., rolrekening nr 1.509. Rekening van Jan Lennoot, waterbaljuw van Mude, over het ambtstermijn 20 sept. 1378 - 10 jan. 1379. - Zie ook bijlage II, nt 12 .

(47) Deze hulk was een van de zeven schepen, die te Plymouth aan de ketting werden gelegd. Zie bijlagen II (nr 13) en III (nr 11).

(48) Bijlage III, nr 9.

(49) Bijlage III, nr 2. 
vracht insloegen ${ }^{50}$. De Vlaamse schippers hadden ongetwijfeld steeds als doel met een volledig geladen schip naar het Zwin terug te keren.

Hoe belangrijk de haring of andere vis, als zoutevis, voor de uitwisseling tegen wijn of andere Franse of Spaanse producten ook was, toch bracht de verkonp ervan in de Westfranse en andere havens niet steeds voldoende kapitaal op om voor de terugreis naar Vlaanderen een even grote vracht wijn of andere koopwaar aan te kopen. Dit zou althans afgelcud kunnen worden uit de vaststelling, dat sommige handelaars, die zelf meereisden, of zelfs schippers, op de tocht westwaarts, naast een lading haring, ook nog een som gelds in speciën bij zich hadden. Aldus vertrok de reeds genoemde Adriaen Tant in het voorjaar van 1378 uit Sluis naar La Rochelle met aan boord van de ,nef", warrvan hij zelf de schipper was, een lading van 22 last gekaakte en 4 last gerookte haring en met zich een bedrag in gouden geldstukken ten belope van 209 frank, wat allemaal door de Engelsen te Plymouth in beslag zou genomen worden ${ }^{51}$. Toch blijken de financiële en boekhoudkundige verrichtingen van de schippers en kooplui tijdens de westvaart nog zeer rudimentair te zijn geweest, wat niet wil zeggen dat ze daarom onderschat dienen te worden. $\mathrm{Zo}$ is er in een klacht, uitgaande van drie Bruggelingen, nopens de arrestatie door de Engelsen van een hele reeks goederen, waaronder zuidvruchten, witte wijn, honig, roet, was, leder en zilverwerk, geladen in een Spaans schip, ook sprake van de papieren, brieven en rekeningen van de meereizende kooplui, evenals van een hoeveelheid niet gemunt blank en zwart zilver uit Spanje en van een wisselbrief, ten bedrage van 80 frank. Deze wisselbrief was door de kooplui aan de schipper, als borg voor het nog te betalen vrachtgeld, voorgeschoten of geleend geworden. Het niet gemunt zilver, dat aan boord van het schip was, vertegenwoordigde een waarde van 32 pond Vlaamse groten ${ }^{52}$.

In de verschillende klachten, die hetzij door de Vlamingen, hetzij door de Engelsen ingediend werden, vinden we de schadeposten in uiteenlopende valuta's berekend. Het zou dan ook de moeite lonen de onderlinge verhoudingen van deze munteenheden na te gaan, wat evenwel een studie op zichzelf vereist ${ }^{53}$. De meeste verliesposten werden evenwel globaal aangeduid, somtijds zelfs met de waarde van het verloren schip inbegrepen, zodat ze in detail niet na te gaan zijn. Wat er ook van zij, voor alle door de Vlamingen en de Engelsen ingediende eisen tot schadevergoeding of herstel konden op de conferentie te Calais van 10 juli 1378 niet steeds onmiddellijke of afdoende oplossingen gevonden worden. Dank zij de daaropvolgende besprekingen te Grevelinge en te Brugge wisten de beide partijen toch te bereiken dat de meeste klachten financieel in der minne zouden worden geregeld ${ }^{51}$.

(50) In Spanje werd „Fronteraby" of Fuenterrabia (heden in het Frans ook Fontarabie) nabij Irun aangedaan. Bijlage II, nr 14. Zie ook bijlage VII. - Voor het graan uit Ponthieu, zie voetnoot 26 .

(51) De Engelse kapers waren herkomstig van „Hamthon", d.i. Southampton. Bijlage III, nr. 3. - Zie ook voetnoot 17 .

(52) Bijlage II, nr 14. - Zie voetnoot 50.

(53) Dit interessant aspect van de hier besproken klachten wordt in een afzonderlijk artikel, volgend op het onze, door professor emeritus $H$. Van Werveke behandeld, waarvoor we hem oprecht danken.

(54) In het verslag van de besprekingen te Calais van 10 juli 1378 vinden we 


\section{DE UITWISSELING VAN HARING TEGEN WIJN IN DE WEST- VAART}

Het belang van de haring, of die nu gerookt of gekaakt was, lag vooral in diens grote waarde als vastenspijs. Beide soorten verduurzaamde vis werden dan ook, na gedurende de vangstperiode bereid te zijn geworden, jaarlijks vóór en in de vastentijd, meer bepaald van oktober tot maart, d.i. in het najaar en het voorjaar, druk verhandeld. Kaakharing kwam toen evenwel uitsluitend uit Schonen, het Deens gebied in het zuiden van Zweden, waar de hanzeaten de productie en de uitvoer ervan monopoliseerden ${ }^{55}$. De grote stapelplaats van deze gereinigde en in tonnen gezouten vis in het westen was sinds 1324 Damme ${ }^{56}$. Vanaf 1372 nochtans mochten te Sluis, waar de hanzeatische schepen aankwamen, Schonense kaakharing, die voor verdere uitvoer over zee bestemd was, tegen de stapeldwang in, maar mits betaling van een buitengewone tol van twaalf groten de last, ter plaats overgescheept worden ${ }^{57}$. De opbrengst van deze heffing, die we in de rekeningen van de waterbaljuw van het Zwin over de jaren 1374 tot 1382 genoteerd vinden, geeft ons een idee van de grote hoeveelheden tonharing,

in de meeste gevallen, na de uiteenzetting van de Vlaamse of Engelse klacht, de opmerking "restitution est faite" of "restitution en est accordee a faire", en, in de rand, soms de nota, "les parties sont d accort". In de overige gevallen volgt op de klacht de verwijzing naar een verder onderzoek of de vraag naar verdere uitleg of verklaring. Zie bijlagen II, III en IV.

(55) Aksel E. Christensen, La foire de Scanie, in La foire (Recueil de la Société Jean Bodin, dl V), Brussel, 1953, blz. 241-266. - J. Travis Jenkins, The berring and the herring fisheries, Londen, 1927, blz. 57-67.

(56) „Item, que toute maniere d avoir venant dedans le Zwin, quel qu il soit, encois que 1 on le vende ou achate, viendra a son droit estaple a Bruges et non ailleurs, dont estape sera, se ce $\mathrm{n}$ est avoir que $\mathrm{I}$ en puet mectre sus au Dam... c est assavoir ... harens en tonniaus...". L. Gilliodts-Van Severen, Coutumes de Sluis (Coutumes des pays et comté de Flandre, Quartier de Bruges, dl V), Brussel, 1893, blz. 503, oorkonde van 9 april 1323 (o.s.).

(57) „Item, ontfanghen van kaecharinghe, die niet $t$ sinen staple te Damme en voer, 12 gr. van der last ...". Brussel, Alg. Rijksarchief, Rekenkamer van Vlaanderen en Brabant, rolrekeningen, nr 1492 (of 1493, dubbel), rekening van Segher van Langmersch, waterbaljuw van Muide, over het ambtstermijn 18 sept. 1374 . 8 jan. 1375, oudste rekening, waarin deze rubriek voorkomt.

Dat de te Sluis geloste kaakharing uit Schonen herkomstig was, blijkt uit volgende uittreksels uit de rekeningen van de waterbaljuw: „Item, ghecalengiert elleven last zes tonnen caecharinx, die toebehoorde Ghuy Buke, Clais de Cupre, Janne van Caleys ende Aernoud Valkenare, denwelken harinc een Jan f. Michiels, meester van eene scepe, in $t$ Zwin brochte van Sconen, ende in $t$ Zwin loste andren harinc huten selven scepe, die ghevoert was ten Damme t sinen staple. Ende de voorseide elleven last zes tonnen behilt binden vorseide scepe ende die ghevoert soude hebben in Normandien, zonder te bringhene ten staple vorseit, waer of de verbuerte es lyf ende goed in s heeren ghenade... Ende es ghepryst elc last vichtich scilde, comt zes hondert vier waerf twintich tien pont (par.)". Ibidem nr 1499 , rekening van Jan Lennoot over het ambtstermijn 22 sept. 1376 - 12 jan. 1377. De 575 schilden stonden dus gelijk aan 690 ponden parisis, wat neerkwam op een berekening van het schild aan een waarde van 24 schellingen parisis of 24 groten Vlaams. - „Item, ghecalengiert 2 last ende 1 tonne caecharinx, die van Sconen in $t$ Zwin brocht was ende toebehoorde eenen Gheeraerd van Zweden, die bastaerd was ende staerf ten Damme, denwelken harinc de bailliu vercocht heift ende daer of ontfaen boven der vrecht 86 lb.". Ibidem nr 1506, rekening van Jan Lennoot over het ambtstermijn 11 jan. - 10 mei 1378. 
die jaarlijks vanuit Sluis opnieuw geëxporteerd werden ${ }^{58}$. Een groot aantal lieden uit Sluis hield zich dan ook, in de hoedanigheid van waarden, kooplui of schippers, met de invoer, verhandeling, overscheping en uitvoer van dit Schonens product bezig. Dit blijkt uit de hieronder staande statistiek, gesteund op de gegevens, voorkomend in de genoemde rekeningen, lopend telkenmale over twee op elkaar volgende ambtstermijnen, namelijk van einde september tot midden januari en van midden januari tot begin mei daarna :

termijnen

oktober 1374 - pasen 1375

januari 1376 - pasen 1376

oktober 1376 - pasen 1377

oktober 1377 - pasen 1378

oktober 1378 - pasen 1379

december 1379 - pasen 1380 aantal warden

\section{boeveelbeden onzgezette kaakharing}

$33 \quad 1.060$ last 1 ton of 12.721 tonnen

$48 \quad 1.479$ last 7 tonnen of 17.755 tonnen

632.044 last 5 tonnen of 24.533 tonnen

632.482 last 3 tonnen of 29.787 tonnen

651.895 last of 22740 tonnen

$48 \quad 1.178$ last 6 tonnen of 14.142 tonnen

In het totaal waren er dus gedurende deze zes jaar, namelijk van oktober 1374 tot pasen 1380 , minstens 10.139 last 8 tonnen of 121.676 tonnen Schonense kaakharing te Sluis over zeer uitgevoerd geworden, wat op een jaarlijkse gemiddelde export van zowat 1.690 last of 20.280 tonnen neerkomt ${ }^{59}$. Tijdens de voornoemde periode waren de twee voornaamste waarden, die zich te Sluis met de omzet van gekaakte haring inlieten, Florens van der Borch en Henri Bast met respectievelijk 1.695 last 9 tonnen of 20.349 tonnen en 587 last of 7.044 tonnen, telkens in het totaal, op hun actief ${ }^{60}$. De meeste andere waarden uit Sluis, die aan makelarij van Scho-

(58) R. Degryse, Scbonense en Vlaamse kdakbaring in de 14de eeuw, in Bijdragen voor de Geschiedenis der Nederlanden, dl XII, 's-Gravenhage, 1957, blz. 100107, rubriek aantekeningen. - De haringvangst vóór de kust van Schonen en Falsterbo, heden in het zuiden van Zweden, werd jaarlijks op 15 augustus ingezet en tot einde september of begin november daaropvolgend voortgezet. Het ligt dan ook voor de hand dat de jaarlijkse invoer van Schonense kaakharing te Sluis en te Damme pas in oktober of nog later een aanvang nam.

(59) D. Degryse, a.w., tabel met de statistiek van de invoer van Schonense kaakharing te Sluis over de jaren 1374 en volgende, naar de rekeningen van de waterbaljuw te Muide. Brussel, Alg. Rijksarchief, Rekenkamer van Vlaanderen en Brabant, rolrekeningen nrs 1492 tot 1517 , met uitsluiting van de rekeningen lopend over de ambtstermijnen mei-september van de betrokken jaren, tijdens dewelke geen kaakharing werd ingevoerd. De berekeningen van de totalen van de ingevoerde kaakharing over de twee op elkaar volgende termijnen september-januari en januarimei zijn gesteund op de opbrengst van de heffing van twaalf groten per last, zoals die in de betrokken rekeningen genoteerd staat.

(60) Naar onze eigen berekeningen volgens de gegevens voorkomend in de betrokken rekeningen van de waterbaljuw van Muide. Ibidem nrs 1492 tot 1513. - Dat Henri Bast waard was, blijkt uit de volgende passage uit de rekening van Segher van Langmersch, waterbaljuw, over het ambtstermijn 18 sept. 1374 tot 8 jan. 1375: "Item, Adam van Monrez ende Fello van Monrez, Scotten, Henri Bast ghasten, ghecalengiert van dat zy 6 tonnen kaecharinx oversceipten omme in Scoland te voerne jeghen den staple en zonder consent van den heere, pais omme $36 \mathrm{lb."}$. Ibidem nt 1492. - Alleen de namen van beide genoemde waarden komen telkenmale in de reeks rekeningen voor. 
nense kaakharing deden, hadden over het algemeen een veel kleinere omzet op hun naam, zelfs somtijds maar enkele tonnen. Niet toevallig vinden we onder al deze makelaars ook de namen terug van degenen, die onder de: Engelse represailles geleden hadden, namelijk, naast Florens van der Borch en Henri Bast, ook Adriaan Tant, Jan en Rik van Cleihem, Jan Blomme, Joris van Roeselare en Pieter Zoete ${ }^{61}$.

In 1372 en volgende jaren werd er ook te Damme, de eigenlijke stapelplaats, nog steeds heel wat Schonense kaakharing aangevoerd en verhandeld, maar hoeveel weten we niet ${ }^{62}$. Wat er ook van zij, de vaststelling, dat, in afbreuk van de stapeldwang, grote hoeveelheden tonharing te Sluis mochten worden gelost en opnieuw over zee uitgevoerd, laat vermoeden. dat de jaarlijkse omzet van dit product in de beide Zwinhavens zo omvangrijk geworden was, dat alleen de uitwisseling tegen wijn en andere producten van de westvaart daarvoor een voldoende verklaring geven kan. Bovendien was daar ook nog de export van inheemse gerookte haring, wat in dezelfde zin gebeurde. Alleen voor Damme kennen we ongeveer de omvang van de jaarlijkse invoer van wijn, althans omstreeks 1379. Dat jaar bedroeg deze import er minstens 10.000 vaten, elk van 900 hedendaagse liters en met een gewicht van zowat 1.000 kilo ${ }^{63}$. Deze ingevoerde wijn was te Damme nochtans geenszins aan de stapel onderworpen ${ }^{64}$, wat ongetwijfeld wijst op de uitwisseling ervan tegen haring.

Het belang van de haring als wisselmunt voor de aankoop van wijn blijkt duidelijk uit een akte van 26 mei 1374, waardoor een minnelijke schikking ten voordele van twee Brugse kooplui, wier goederen in Engeland gearresteerd waren, tot stand kwam. Johan Kaerlyn uit Brugge had 20 last of 240 tonnen kaakharing in een schip uit Sluis, de "Sint-Jacob”, geladen en zijn stadsgenoot Jacob Hogennese 8 last en 2 tonnen of 98 tonnen van dezelfde waar in en vaartuig uit Hulst, de "Sinte-Maria", om ze westwaarts

(61) Jan van Cleihem vonden we alleen vermeld in de rekeningen van Jan Lennoot over de ambtstermijnen 14 jan. - 9 mei 1376 en 22 sept. 1376 - 12 jan. 1377, respectievelijk in verband met de invoer van 54 last en 54 last 8 tonnen kaakharing. Ibidem nrs 1495 en 1499.

Joris van Roeselare staat vermeld in de rekeningen van genoemde waterbaljuw over de ambtstermijnen 21 sept. 1377 - 11 jan. 1378 en 11 jan. - 10 mei 1378, respectievelijk in verband met de invoer van 62 last en 29 last kaakharing. Ibidem nrs 1504 en 1506.

De overige betrokken waarden vinden we o.a. vernoemd in de rekening van dezelfde waterbaljuw over het ambtstermijn 12 jan. - 11 mei 1377 in verband met de volgende invoer: Florens van der Borch 144 last kaakharing, Henti Bast 17 last, Adriaan Tant 6 last, Jan Blomme 13 last 6 tonnen en Pieter Zoete 5 last. Ibidem nr 1500. - De rekeningen vermelden voor iedere waard zowel de hoeveelheid verhandelde kaakharing, als de verschuldigde en betaalde tol.

(62) In de periode dec, 1382 - mei 1383 betaalden de Oosterlingen te Damme een oorlogsschatting voor 612 (of 712?) last door de graaf aangeslagen kaakharing. N. De Pauw, Froissart's chronijke van Vlaenderen, vertaling door Gerijt Potter van der Loo, a.w., dl. II, blz. 162, rekening van de verbeurdverklaringen te Damme over genoemde periode. - R. Degryse, Schonense en Vlaamse kaakharing, a.w., blz. 104 .

(63) Jan Craeybeckx, a.w., blz. 22 en 23, naar Rijsel, Arch. dép. du Nord, série B, nr 4.069, recette générale de Flandre, année 1379-1380. De desbetreffende wijn was herkomstig uit Poitou.

(64) Ibidem. 
naar Frans gebied, meer bepaald Normandië, te laten voeren en aldaar aan de man te brengen. $\mathrm{Na}$ gedane zaken werd voor rekening van de eerste van de beide Bruggelingen in Normandië 40 vaten of 80 pijpen wijn en voor rekening van de tweede 55 vaten of 110 pijpen van dezelfde drank in genoemde schepen ingeladen, om met die vracht naar Vlaanderen terug te keren. De beide vaartuigen werden evenwel op zee door de Engelsen gepraaid en als vijandelijk goed naar Sandwich in Kent opgebracht. Dank zij de vertegenwoordigers van de Drie Leden van Vlaanderen, Brugge, Gent en Ieper, waarbij zich ook de afgevaardigde van het Brugse Vrije gevoegd had, werden de twee Brugse kooplui in Engeland opnieuw in het bezit van hun ladingen wijn gesteld, op voorwaarde evenwel er in toe te stemmen de Engelse koning te vergoeden door betaling van de tegenwaarde van de in Normandië verkochte kaakharing ${ }^{65}$. Interessant in deze akte is de vermelding van de uitwisseling van 20 last kaakharing, elk van 12 tonnen, tegen 40 vaten of 80 pijpen wijn, wat zou kunnen duiden op de gelijkstelling in vracht van een last kaakharing met twee vaten of vier pijpen wijn ${ }^{66}$.

In de Vlaamse klachten van 1378 en 1379 treffen we verschillende soortgelijke voorbeelden van uitvoer van haring aan. Van vóór het einde van het bestand tussen Engelsen en Fransen dateert waarschijnlijk de schade, waarvan de Bruggeling Hector van Mulhem te klagen had. Deze koopman had in een schip uit Terneuzen, de "Crucembergh", 12 last of 144 tonnen kaakharing met bestemming naar Rouen in Normandië geladen, vracht, die door Engelse kapers onder leiding van Thomas Pery geroofd en naar Winchelsea in Sussex gevoerd werd ${ }^{67}$. Een soortgelijke klacht ging uit van Pieter Zoete uit Sluis, die in een vaartuig van een medeburger drie last

(65) „que de les dites niefs, la nief appellee seinte Jaques de 1 Escluse, dont Guillaume N...re de 1 Escluse estoit mestre, fuist chargee de vynt lastes de cakeharenz appartenantz a Johan Kaerlyn de Bruges, et la nief appellee seinte Marie de Hulst, dont Johan Caerscietere de Hulst estoit mestre, fuist chargee de oyt lastes et deux cokets de cakeharengz appartenantz a Jaquemon Hoghennese de Bruges, pur amesner en estrange paiis, et par les cartes soit aussi trovez, que les dites deux niefs, en retournant vers Flandres, contenoient, $c$ est assavoir la dite nief appellee seinte Jaque quarante toneux de vyn, deux pipes contees pur un tonel, appartenantz au dit Johan Kaerlyn, et la dite nief appelle seinte Marie cynquante et cynk toneux de vyn, contees deux pipes pur un tonel, appartenantz au dit Jaquemon Hoghennese, chargez... en Normandie, parout le dit noble conseil supposent evidentement que tout le dit hareng estoit amesnez as Normandz, enemys du dit Roy, et ensi la forfaiture de mesme le harengs de droit appartenir a mesme le Roy... Si empreignons nous... que en cas, kil plest an dit Roy que son attornez en son noum pursue, pardevers nostre dit seigneur le conte, pur le recoverir de la vraie value du dit hareng, come au dit Roy forfait..., notre dit seigneur le conte ent ferra plein droit... et come de quanque serra iugger par mesme nostre seigneur le conte d estre paiez au dit Roy pur le dit hareng plein paiement...". Ed. Scott et L. Gilliodts van Severen, Documents pour servir à l'bistoire des relations entre l'Angleterre et la Flandre de 1431 à 1473, Galba Cotion manuscript B I, Brussel, 1896, blz. 517, aanvulling E, document uitgaande van de vertegenwoordigers van de Leden van Vlaanderen, opgesteld te Londen. - Betreffende Jaquemon Hoghennese of Hoghenuese, zie ook bijlage III, nr 9 .

(66) Daar een last ongeveer 1.800 kilogram woog, stond zij in gewicht gelijk aan twee vaten wijn. J. Craeybeckx, a.w., blz. 284.

(67) Bijlage II, nr 18. 
haring geladen had, ten einde die te versturen naar een Seinehaven. Gekomen vóór de Hoofden, de zandbanken aan de ingang van het Nauw van Calais, werd het schip door een ,baardse”, behorend aan de heer van Latimer, gepraaid en naar Londen opgebracht, niettegenstaande de bewijzen van borgstelling, die in verband met de lading voorgelegd konden worden ${ }^{68}$. Beide klachten werden op de conferentie van Calais van 10 juli 1378 behandeld als slaande op represailles gebeurd "depuis 2 ans encha", d.i. binnen de twee laatste jaren. Het blijkt wel dat de klagers nadien voldoening kregen ${ }^{69}$. Een ander geval, dat op dezelfde conferentie geregeld kon worden, was dit van een vijftal kooplui uit Nieuwpoort, Duinkerke, SintWinoksbergen en Broekburg, die op zee door de Engelsen van meer dan 48 last gekaakte en gerookte haring, benevens van een zekere hoeveelheid gezouten vis, geladen in drie schepen, beroofd geworden waren. Deze buit aan vis zou de Engelse kapers in het totaal 705 nobels opgebracht hebben, som die aan de klagers terugbetaald werd, gedeeltelijk onder de vorm van speciën en gedeeltelijk onder die van een obligatiebrief ${ }^{70}$. Uit dit geval zouden we kunnen afleiden dat sommige ladingen haring niet zozeer voor het buitenland, dan wel voor westelijk Vlaanderen, dus voor eigen streek, bestemd waren ${ }^{71}$.

Op te merken is, dat sommige klagers, waaronder vooral lieden van Sluis, zoals Pieter Zoete, Adriaen Tant en Henri Bast, in verband met de Engelse represailles, verschillende malen aanbod komen, wat toelaat hun veelzijdige activiteiten als schippers, reders of handelaars beter na te gaan. Zo zien we Adriaen Tant in het voorjaar van 137822 last gekaakte en 4 last gerookte haring en in april van het volgend jaar zelfs niet minder dan 32 last 3 tonnen kakharing westwaarts voeren en ervan door de

(68) Zie bijlage II, nr 16 (anno 1378) en bijlage III, nr 7 (anno 1379). Dezelfde klacht werd inderdaad voorgelegd, zowel op de conferentie te Calais, als op die te Brugge in genoemde jaren.

(69) De aan de kaak gestelde feiten kunnen in 1377 plaats gegrepen hebben. Onder de klacht van Hector de Mulhem staat de opmerking:, ,restitution en est accordee a faire a la dite journee" (te Grevelinge op 25 november 1378). Dit kan ook zo geweest zijn voor Pieter Zoete, vermits diens klacht in de lijst, door de lieden van Sluis in 1379 ingediend, doorstreept of geannuleerd werd. Zie bijlage III, $\mathrm{nr} 7$.

(70) Zie Bijlage II, nr 1.

(71) Dat sommige lieden van Duinkerke of Nieuwpoort kaakharing in eigen haven invoerden, blijkt uit volgende passages uit de rekeningen van de waterbaljuw van Muide: „Item, ghecalengiert Jan Cant en Jan Pauwel van Dunkerke, van dat zij 13 last caecharinx brochten van Zerixee in $t$ Zwin ende oversceepten te Slepeldamme, omme te voerne te Dunkerke, zonder te voerne ten Damme $t$ sinen rechten staple. Ende waren der mede ghezeilt in de zee, daer ze de bailliu vorseid achter volghede, denwelken harinc de bailliu vornoemd vercocht heeft ende daer of ontfang te mijn gheduchts heeren bouf vornoemd, boven vrechte ende coste van achtervolghenne, 606 lb.". Gent, Rijksarchief, Rekenkamer van Vlaanderen en Brabant, nr 2897 (vroeger te Brussel nr 1495 bis) - Zelfde rekening te Rijsel, Arch. dép. du Nord, B 6.004. Rek. van Jan Lennoot over het ambtstermijn 12 jan. - 7 mei 1375.

„Item, ghecalengiert Heinric Maes van der Nieuwpoort, van dat hi brochte in t Zwin van Zerixee 14 tonnen caecharinx, dewelke hi oversceepte om te voerne ter Nieuport jeghen den stapel van den Damme, waer of de verbeurte es lijf ende goed in ts heeren ghenaden, pais omme $60 \mathrm{lb}$.". Brussel, Alg. Rijksarchief, Rekenkamer van Vlaanderen en Brabant, nr 1518 (of 1519, dubbel), rekening van Jan Lennoot over het ambtstermijn 4 mei 1383 - 2 maart 1384. 
Engelsen beroofd worden ${ }^{72}$. Dezelfde reder en koopman liet zich evenwel ook in met import van wijn in Vlaanderen, wat blijkt uit een schadepost van 8 tonnen wijn, waarin hij een aandeel had en die in 1378 te Plymouth door de Engelsen aangeslagen geworden waren ${ }^{73}$. Soortgelijke manier van handelen en zaken drijven zien we ook bij Henri Bast, die we vooral als waard kennen. De hulk, waarin deze makelaar een vierde deel had, behoorde tot de zeven schepen, die in het voorjaar van 1378, door de Engelsen gepraaid of te Plymouth aan de ketting werden gelegd. Het vaartuig, dat voor rekening van Franse kooplui wijn vervoerde, was te Fontenay in Poitou gekaapt geworden om vervolgens naar Engeland te worden opgebracht. Henri Bast, die daardoor een verlies van 50 pond Vlaamse groten leed, was dus slechts als vennoot en aandeelhouder bij de uitbating van het vrachtschip opgetreden ${ }^{74}$. Dezelfde Henri Bast was het wellicht ook, die het jaar nadien, in de loop van april 1379 , een groot verlies boekte, toen Engelse kapers zich van een kogge uit Sluis, de "Sint-Christoffel", geladen met 16 last gerookte en gekaakte haring, 100 delen haver, 1.000 plankjes en 200 schoven knoflook en op weg naar Bordeaux, meester maakten. Hij en zijn geassocieerden, allen burgers uit Sluis, bezaten immers drie vierden van het vaartuig, terwijl het overige vierde deel behoorde aan de Bruggeling Jacob Hogheneuze. Bovendien was genoemde Henri Bast de vennoot van een paar andere kooplui voor wat betrof een gedeelte van de haring, namelijk 4 last gerookte en 2 last gekaakte, en van het knoflook. Zijn voornaamste vennoot was evenwel Joris van Roeselare, wiens verlies, naast zijn participatie in de kogge, bestond uit 5 last gekaakte en $21 / 2$ last gerookte haring. Zo zien we nogmaals hoe de associatie tussen reders en kooplui in de westvaart een noodzaak was. Ongetwijfeld lag het in de bedoeling van Henri Bast en zijn vennoten, na de verkoop van hun goederen te Bordeaux, met wijn naar Vlaanderen terug te keren ${ }^{75}$.

Een ander voorbeeld van het optreden van de handelaars uit Sluis is de handelwijze van de gebroeders van Cleihem, die blijkbaar eveneens haring tegen Franse wijn uitwisselden. In het voorjaar van 1378 zien we althans Jehan van Cleihem en zijn broer Filips op zee beroofd worden van 21 tonnen zulke drank, die zij van La Rochelle naar Vlaanderen vervoerden ${ }^{76}$. Dezelfde Jehan van Cleihem en zijn andere broer Rike verloren dat jaar ook, omstreeks midden november, 19 last gerookte haring in de haven van Chichester in Sussex, niettegenstaande de vracht in de grafelijke baardse geladen was. Of zij daarbij op weg naar Frankrijk waren, is minder duidelijk. Uit de desbetreffende klacht vernemen we wel, dat Jehan van Cleihem zelf niet mede op reis gegaan was, maar zichzelf en zijn vennoten door zijn broer Rike had laten vervangen en dat die broer samen met de schipper

(72) Bijlage III, nrs 3 en 5.

(73) Deze klacht, maar zonder de vernoeming van Adriaen Tant, werd reeds op de conferentie te Calais van 10 juli 1378 besproken. Bijlagen II ( $\mathrm{nr} 10$ ) en III ( $\mathrm{nr} 8$ ).

(74) Bijlagen II ( $\mathrm{nr}$ 13) en III ( $\mathrm{nr} 11$ ).

(75) Bijlage III, nr 9. - Het betrof hier „Henri Bast, le pere”, wat veronderstelt dat er ook een Henri Bast junior was, maar die vonden we niet als dusdanig vermeld. De Engelse kapers waren Symon Pavez en zijn kornuiten uit Sandwich.

(76) Bijlage III, nr 1. - De Engelse kapers kwamen uit Dartmouth. 
van de baardse twee weken lang door de graaf van Arundell gevangen gehouden werd ${ }^{77}$.

Uit de activiteiten van Adriaen Tant, Henri Bast en de gebroeders van Cleihem zou kunnen afgeleid worden, dat heel wat waarden te Sluis zich met de uitwisseling van verduurzaamde vis tegen wijn en andere producten, door de westvaart opgeleverd, inlieten. Indien zo, dan mogen we veronderstellen dat ook in die tijd de voornaamste waard aldaar, namelijk Florens van der Borch, dit deed, maar een positief bewijs daarvoor vonden we niet. In het voorjaar van 1379 nochtans zien we hem, in associatie met zijn stadsgenoot Pieter Zoete, 13 last kakkharing naar de Sommemonding of verderop versturen, lading die evenwel op zee door een Engelse kaper geroofd en als buit naar Dover opgebracht werd ${ }^{78}$. Voor het overige vernemen we, dat onder de goederen geladen in de Vlaamse schepen, die, komend van La Rochelle, in het voorjaar van 1378 door de Engelsen naar Plymouth geleid of aldaar gearresteerd werden, er zich vooral wijn bevond ${ }^{79}$. We hadden het reeds over de "nef" van Jehan de Mol uit Biervliet met een vracht van 153 vaten en 1 pijp van deze drank. Jehan de Riethane uit Damme en zijn vennoten bezaten in deze lading 66 vaten, die ze tegen de prijs van 600 frank aangekocht hadden. De overige 87 vaten en 1 pijp waren het bezit van drie andere Vlaamse handelaars, waaronder de schipper zelf ${ }^{80}$. Een van de andere te Plymouth gearresteerde schepen vervoerde 102 vaten wijn, waaronder 68 behorend aan Wouter Goederic uit Damme en 24 aan Pieter Plume uit Monnikenrede ${ }^{81}$. Altezamen is er in de betrokken zeven klachten sprake van 288 vaten en 3 pijpen wijn ${ }^{82}$.

De twee documenten betreffende de Engelse represailles bevatten nog heel wat bezonderheden over de invoer van wijn, graan, zout, wol, as en lood en de uitvoer van andere producten door kooplui uit Brugge, Damme en Sluis. Zo zien we Jehan Blomme, een waard uit Sluis, die we als makelaar in Schonense kaakharing kennen ${ }^{83}$. zich inlaten met de handel in smeer en graan. Op de conferentie te Calais van 10 juli 1378 werden inderdaad twee klachten van hem behandeld, namelijk het verlies van 24 tonnen smeer van vetvis, genaamd,,sain de malemort", en dit van 16 mudden graan. Voor het vervoer van deze vrachten had Jehan Blomme beroep gedaan respectievelijk op een schip uit Duinkerke en op een uit Nieuwpoort. Voor het verloren smeer werd hem een vergoeding in geld uitgekeerd, namelijk 15 pond sterling, zijnde de waarde ervan naar een

(77) Het verlies van de beide broers werd op 132 pond Vlaamse groten geschat, inbegrepen 20 nobels voor uitgaven in Engeland. De represaille zelf gebeurde omstreeks 11 november 1378. Bijlage III, nr 2.

(78) De roof moet omstreeks maart of althans in het voorjaar 1379 plaatsgegrepen hebben. Bijlage III, nr 6. - De Engelse kaper was Symekin Pavez uit Dover. Zie nopens hem ook voetnoot 75 .

(79) Bijlagen II (nrs 7 tot 13) en III (nrs 8 en 11), waar slechts zes schepen opgesomd worden. Zie voetnoot 17 .

(80) Bijlage II, nrs 7 en 8 . - Zie ook voetnoot 44.

(81) Bijlage II, nr. 9. - Vijf vaten wijn behoorden aan Jehan de Tournay. Zie nopens deze Bruggeling voetnoot 15 .

(82) Daaronder was er één, ,pipe de florat". Bijlage II, nr 9.

(83) Zie voetnoot 61 . 
schatting gemaakt door twee deskundige kooplieden ${ }^{84}$, terwijl voor het verlies van het graan een afzonderlijke regeling met de kapitein van Calais in het vooruitzicht werd gesteld ${ }^{85}$. Moeilijker te regelen was de schade geleden door Jehan van der Pale en zijn vennoten uit Sluis, op wier ladingen graan, zich bevindend in drie schepen en bedragend in het totaal zowat 900 hoet of ongeveer 600 kwartier, volgens Engelse inhoudsmaat, te Calais beslag gelegd was. Weliswaar kon een regeling getroffen worden voor de teruggave of de vergoeding van 650 hoet ${ }^{86}$, maar voor wat betrof de schadeloosstelling voor het verlies van het overige graan, beperkt tot een hoeveelheid van 200 hoet, diende beroep te worden gedaan op de waterbaljuw van het Zwin, die te Sluis tot represailles ten nadele van Engelse kooplui overging, om aldus zowel Jehan Blomme voor het verlies van zijn smeer, als Jehan van der Pale en diens vennoten voldoening te geven ${ }^{87}$. Voor wat aanging de invoer van zout uit de baai van Bourgneuf, is daar het voorbeeld van Jehan Kant, Jehan Ponthieu en Gilles Joerdaen, drie burgers uit Duinkerke, die gezamenlijk een kogge uitgerust hadden om daarmee naar de Baai te varen, maar dit schip verloren toen het omstreeks Pinksteren van het jaar 1378 op zee door een smaldeel van de Engelse vloot, geleid door admiraal Arundell, gepraaid werd ${ }^{88}$.

Het spreekt vanzelf dat sommige vaartuigen tijdens de westvaart heen en terug niet uitsluitend met één enkele soort handelswaar als vis, wijn, graan of zout geladen waren. Zo behandelde de conferentie te Calais ook het geval van Jehan Uuten Broeke, koopman uit Brugge, die door de Engelsen beroofd geworden was van 10 last as, 8 stukken lood en 104 tonnen wijn van groot en klein formaat, wat neerkwam op een verlies van 47 pond Vlaamse groten. Hij werd evenwel gedeeltelijk vergoed door de betaling van 30 pond Vlaamse groten, zijnde de opbrengst van de verkoop van die goederen ${ }^{89}$. Voor het overige werd op dezelfde conferentie nog geen regeling gevonden voor het verlies geleden door Everard Goederic, Willem van Cleyhem en Morissis van Crayenbrouc, drie Bruggelingen, die in een Spaans schip allerhande goederen als zuidvruchten, witte wijn, honig, roet, was, leder en zilver geladen hadden, waarvan de Engelsen zich naderhand op zee meester maakten, om ze naar Plymouth op te brengen. Weliswaar werd dienaangaande door de raad van de Engelse koning overeengekomen een onderzoek in te stellen, om, aan de hand daarvan, op de volgende conferentie, die te Grevelinge gehouden zou worden, gebeurlijk een beslissing inzake schadevergoeding te treffen ${ }^{90}$. Of

(84) Bijlage II, nr 5. - Smeer van vetvis was, zoals de kaakharing, een product, dat door de Vlamingen uitgevoerd werd. Zo zien we in 1344 een Brugse schuit te Calais een drietal tonnen ,sain de malemort" lossen. F. Lennel, Calais au moyen âge. Des origines au siège de 1346, Calais, 1909, blz. 210.

(85) Bijlage II, nr 6.

(86) Bijlage II, $\mathrm{nr} 3$.

(87) Bijlage II, nr 23.

(88) De dag vóór Pinksteren 1378: 6 juni. Bijlage II, nr 2. - Betreffende Jehan Kant uit Duinkerke, zie ook voetnoot 71 .

(89) Bijlage II, nr 4. - De kapers kwamen uit Romney en Hythe.

(90) Bijlage II, nr 14, klacht over een feit gebeurd "depuis 2 ans encha", dus van vóór 1378 . - Zie voetnoot 50. 
dit aldaar werkelijk gebeurd is, weten we niet, maar vermits we naderhand over deze zaak niets meer vernemen, is het mogelijk dat inderdaad een of andere regeling tot voldoening van de klagers uitgewerkt geworden was.

Van de Vlaamse westvaart zijn heel wat sporen in de rekeningen van de waterbaljuw van het Zwin te bespeuren. Deze grafelijke politieofficier had immers de vervolging en bestraffing van de overtredingen van het maritiem recht, waaronder ook misdaden als diefstal, handgemeen en moord, in zijn bevoegdheid. Zo vinden we dan ook in zijn rekeningen heel wat opsommingen van beboetingen wegens feiten gebeurd op de schepen of onder Vlamingen in vreemde havens. Onder deze havens komen Bordeaux, La Rochelle, de baai van Bourgneuf en de Bretoense baaien en steden op de eerste plaats ${ }^{91}$. In mindere mate vinden we soortgelijke vermeldingen in rekeningen van de baljuws van Duinkerke en Nieuwpoort, die eveneens maritieme delicten mochten doen vervolgen ${ }^{92}$. Uit deze verspreide gegevens van strafrechterlijke aard is evenwel nogmaals de deelname van de Vlamingen aan de koopvaardij in westelijke richting in de tweede helft van de 14 de eeuw af te leiden.

\section{DE ENGELSE KLACHTEN OVER DE VLAMINGEN}

Op de conferentie te Calais van 10 juli 1378 werd ook aandacht besteed aan een reeks klachten van Engelse kooplui tegen Vlaamse schippers of handelaars, hun geassocieerden, en de admiraal van Vlaanderen, Matthys Claissone ${ }^{93}$. Geroepen om zich aangaande de tegen hen uitgebrachte beschuldigingen te verantwoorden en de door de Engelse gestelde eisen te aanhoren, dienden de betichte Vlamingen bij hun verschijning vóór de grafelijke raad verweerschriften in, waarin ze uiteenzetten wat, volgens hen, de ware toedracht van de aan de kaak gestelde feiten geweest was ${ }^{94}$. De Engelse aanklachten en de Vlaamse verweerschriften vullen elkaar dientengevolge goed aan. Het ging meestal om Vlaamse schippers, varend in opdracht van of in associatie met Engelse handelaars naar Portugal,

(91) „Item, ghecalengiert Coppin Jan Lippins zone, van zestich ponden van twiste ghevallen te Bordeaux jeghen Heine van Zeelant, pais omme $36 \mathrm{lb} . "$. „Item, ghecalengiert Boudekin de Gloeyere ende Heinekine van Denremonde, van 60 ponden van twiste ghevallen te Rocheelle, d een jeghen den andren, pais omme 12 lb.". - "Item, ghecalengiert Gheeraert den Hertoghe, van dat hi ghenomen zoude hebben uute eenre crake, die d Inghelsche ghenomen hadden in Bertaengen, 4 meezen droochs harinx, zonder dat den bailliu te kenne te ghevene binden darden ghetide, dat hi in $\mathrm{t}$ Zwin commen was. Ende van dat een zijn neve ghetwist zoude hebben in de Baye ... Pais van al omme $48 \mathrm{lb.".} \mathrm{Brussel,} \mathrm{Alg.} \mathrm{Rijksarch.,} \mathrm{Reken-}$ kamer van V1. en Brab., rolrekening nr 1496, rekening van Jan Lennoot, waterbaljuw, over het ambtstermijn $7 \mathrm{mei}$ - 17 sept. 1375. - Soortgelijke voorbeelden vindt men ook in de volgende rekeningen.

(92) „Dankaert Clais f Gheraerds, om dat hi berucht was, dat hi te Rutseele een man sijn been brac met eenen vate wijns, daer of ghecomposeert om 3 lb.". Ibidem, rolrekening nr 1540, rekening van Raes Mulox, baljuw van Nieuwpoort, over het ambtstermijn 11 jan. - 10 mei 1378.

(93) Bijlagen I en II.

(94) Bijlagen V. VI, VII, IX en $\mathrm{X}$. 
Spanje en Bordeaux, om er wijn te halen, of naar Calais, om er wol te lossen. Naast een paar gevallen van Vlaamse schippers, die van vervreemding van de hen toevertrouwde goederen beschuldigd werden, somde de Engelse klachtenlijst ook enige roofovervallen op zee, alsmede enkele represailles te Sluis op. Over het onderzoek naar de geloofwaardigheid van de aangeklaagde gebeurtenissen vernemen we, buiten de Vlaamse verweerschriften, niets verder ${ }^{95}$. Wel blijkt het dat op de conferentie beide partijen het meestal met de voorgestelde procedure tot onderzoek of tot regeling van de schadeloosstelling eens waren ${ }^{96}$.

Aan de kapitein van de Vlaamse westvloot of admiraal van Vlaanderen werd door de Engelsen niet alleen verweten van de lieden van Plymouth een door hen gekaapt Spaans schip en een kraaier te hebben geroofd, maar daarbij ook eenentwintig personen te hebben vermoord ${ }^{97}$. Tegenover deze aantijging en de erbij gevoegde eis tot een schadevergoeding van 2.000 pond sterling wisten Matthys Claissone en zijn gezellen in hun verweerschrift de juiste toedracht van de gebeurtenissen te belichten en aldus de bal terug te kaatsen ${ }^{98}$. De admiraal werd door de Engelsen evenwel ook beschuldigd van de beroving van een kogge, geladen met zout en wijn, in de baai van "Tristam" in Bretagne, wat een eis tot schadeloosstelling ten bedrage van 400 pond sterling voor gevolg had ${ }^{99}$. Deze zaak, waarover we later niets meer vernemen, werd, zoals een paar andere gevallen, op de agenda van de conferentie te Grevelinge van 25 november geplaatst, maar of die samenkomst werkelijk plaats vond, weten we niet 100 .

Enkele Engelse handelaars beschuldigden Vlaamse schippers en reders, wier vaartuigen ze voor het vervoer van hun goederen in dienst genomen hadden, ervan hen door roof schade te hebben berokkend. Aldus betichtte Thomas Sir, koopman uit Bristol, de schipper Pieter Stoker uit Sluis ervan hem 25 vaten wijn, die van Portugal naar Londen moesten worden vervoerd, afhandig gemaakt te hebben, door met die vracht naar de Zwinhaven te zijn gevlucht ${ }^{101}$. Op deze aantijging antwoordde Pieter Stoker

(95) Wel hebben we het verslag van het onderzoek op 3 december 1378 door de grafelijke commissarissen te Oostende ingesteld in verband met de Engelse klacht als zouden Vlaamse zeelui een vaartuig, geladen met vis en toebehorend aan een reder uit Southam, gekaapt en de bemanning ervan uitgemoord hebben. Zie bijlage VIII.

(96) De betichte Vlaamse zeelui, waaronder de admiraal, zouden vóór de grafelijke raad geroepen worden, wat de indiening van hun verweerschriften voor gevolg had. Voor het overige werden de Engelse klagers naar de volgende conferentie verwezen. Zie bijlage II.

(97) In de tekst is er sprake van een Spaanse, ,nef de 180", waarmede ongetwijfeld een schip met een draagvermogen van 180 ,,tonneaux" of vaten bedoeld werd. Bijlage II, nr 25.

(98) Bijlagen IV (nr 5) en X.

(99) Dit geval blijkt gemakkelijk opgelost te zijn geworden, aangezien het op de conferentie te Brugge van 26 mei 1379 onbesproken bleef. Zie de bijlagen II ( $\mathrm{nr}$ 20) en IV.

(100) Heel waarschijnlijk werd de conferentie, die te Grevelinge gehouden moest worden, verdaagd en naar Brugge verplaatst, waar ze op 26 mei 1379 doorging. Zie bijlage IV.

(101) Bijlage II, nr 21. - Zie betreffende een ander vluchtmisdrijf van Pieter Stoker voetnoot 11 . 
met een verweerschrift, waarin hij betoogde op zee, nabij Sandwich, door Engelse vrijbuiters beroofd te zijn geworden en eerst daarna, vluchtend voor een opkomende storm, maar ook voor Normandische kapers, van Calais naar Sluis de wijk te hebben genomen, reden waarom hij zich te Damme voor de schepenbank had moeten verantwoorden, zonder dat hij er voor de schade, die hij zelf geleden had, enige vergoeding had kunnen bekomen ${ }^{102}$.

Een andere klacht ging uit van de Londense handelaar Jehan Edrop en zijn vennoten en betrof Ghijs Cudel, schipper uit Sluis, die met een kogge, waarvan Jaque Crakebeen en Pieter Crooc, twee Bruggelingen, de eigenaars waren, 160 vaten wijn van Bordeaux naar Londen te vervoeren had, maar die vracht, na uit de Engelse vloot te zijn gevlucht, in de handen van de Fransen gespeeld had, verlies, waarvoor een schadeloosstelling van 640 pond sterling werd geëist ${ }^{103}$. In antwoord op deze aantijging verklaarden Jaque Crakebeen en zijn vennoten, dat hun schip op zee door de Normandiërs als vijandelijk goed gekaapt geworden was en dat zijzelf daardoor een verlies geleden hadden van minstens $1.800 \mathrm{frank}$, die niet werden vergoed, niettegenstaande een schriftelijke aanmaning van de Franse koning tot de autoriteiten in Normandië om het vaartuig met zijn lading vrij te laten en een poging van schipper Ghijs Cudel om, door het opbrengen naar Engeland van twee schepen geladen met Normandische goederen, op de Fransen de geleden schade te verhalen. Verder betoogden ze in hun verweerschrift, dat de Engelsen dat allemaal zeer goed wisten, aangezien ze Ghijs Cudel gevangen genomen hadden en nog steeds in het gevang hielden ${ }^{104}$. Bij hun antwoord voegden Jaque Crakebeen en zijn gezellen de tekst van de brief, die ze vanwege de Franse koning verkregen hadden en die tot de kapers van Saint-Valéry gericht was, met de dringende aanmaning het vaartuig met de gekaapte goederen aan de rechthebbenden terug te geven ${ }^{105}$, wat niet gebeurd was.

Nog een andere klacht was geuit door Nicholas Brembre en Jehan Phillipot, twee Londense kooplui, tegen hun geassocieerde schipper uit Sluis, Jehan Belle, aan wie ze het vervoer naar Calais van twintig zakken wol toevertrouwd hadden, maar die zogezegd die vracht zou hebben laten verdonkermanen door Wouter Janssone, zijn plaatsvervanger, om ze in Normandië aan de man te brengen, waardoor ze een verlies van 450 mark sterling zouden geleden hebben ${ }^{106}$. In zijn verweerschrift dienaangaande beklemtoonde Jehan Belle zijn goede trouw door erop te wijzen, dat zijn geassocieerden beter dan hij wisten dat Wouter Janssone, die hem als schipper verving, te Londen bij het dobbelspel geld verloren en schulden gemakt had, zodat zij, door dit wangedrag verwittigd, zouden hebben kunnen ingrijpen, indien ze dit gewild hadden. Verder betoogde hij dat hij voor het overige zich met Nicholas Brembre, in zake de uitkering van diens aandeel in de winst van het schip, waarvan zij beiden voor elk de helft

(102) Bijlage VII.

(103) Bijlage II, nt 19.

(104) Bijlage V.

(105) Bijlage VI.

(106) Bijlage II, nr 24. 
de eigenaars waren, volledig in regel gesteld had ${ }^{107}$.

Op de conferentie te Brugge van 26 mei 1379, alwaar de klachten van Thomas Sir, Jehan Edrop en Nicholas Brembre en hun vennoten nogmaals voorgelegd werden, antwoordden de leden van de grafelijke raad met een verwijzing naar de door Pieter Stoker, Jaque Crakebeen en Jehan Belle ingediende verweerschriften, wat ongetwijfeld op een afwijzing neerkwam. Dat was eveneens zo voor de klacht van de lieden van Plymouth tegen Matthys Claissone en zijn gezellen voor wat de zaak van de gekaapte of beter gerecupereerde kraaier en het bevrijde Spaanse schip betrof ${ }^{108}$. Tijdens de besprekingen te Brugge werd door de grafelijke raadslieden ook verslag uitgebracht over het onderzoek te Oostende nopens de roof door de zeelieden van twee Vlaamse vissersvaartuigen, waaronder een met een rood doek in zijn zeil, van een Engels schip geladen met vis en de uitmoording van twaalf leden van diens bemanning ${ }^{109}$. Ook deze Engelse aanklacht werd, als niet bewezen zijnde, afgewezen ${ }^{110}$. Anders was het gesteld met het verzoek van Thumas Gindalier, uit Londen, die in een kogge uit Dantzig 85 dozijn lakens geladen had met het doel die naar Pruisen te versturen, maar zijn goederen verloor, toen het schip, door storm gedwongen, in het Zwin aankwam en de waterbaljuw aldaar, buiten de haven van Sluis, tot de confiscatie ervan overging ${ }^{111}$. De leden van de grafelijke raad, ingaande op de opmerking van de klager door de schriftelijke tussenkomst van de Engelse koning bij de graaf reeds meermaals op de teruggave van zijn bezit te hebben aangedrongen, antwoordden in gunstige zin, door te laten uitschijnen, dat, indien de zaak in de eerste plaats onder het heerlijk recht van de vorst ressorteerde, het toch in laatste instantie van de Engelse tegemoetkoming op de Vlaamse klachten zou afhangen om voldoening te verwachten ${ }^{112}$. In een paar andere gevallen, waarbij de waterbaljuw te Sluis goederen behorende aan Engelsen, waaronder lakens bestemd voor Calais en Rijnlandse wijn, in beslag genomen had, was inderdaad door de klagers restitutie bekomen geworden ${ }^{113}$.

In de loop van 1379 begonnen de Normandische kapers in hun strijd tegen de Engelsen de zeeweg langs de Vlaamse kust zodanig onveilig te maken, dat de graaf diende in te grijpen door aan de zeelieden van de kuststreek opdracht te geven zich klaar te maken om uit te varen ten einde tegen de rovers op te treden ${ }^{114}$. De besprekingen met de vertegenwoor-

(107) Bijlage IX.

(108) Bijlage IV, nrs $1,2,4$ en 5.

(109) Bijlage II, nr 22.

(110) Bijlagen IV ( $\mathrm{nr} 3$ ) en VIII.

(111) Bijlage II, nr 26.

(112) Bijlage IV, nt 5.

(113) Bijlage II, nrs 23 en 27, twee klachten, die naderhand niet meer ter sprake kwamen.

(114) „Item, zende me myn heere te Heys ende Blankenberghe, $t$ Oostende, ter Nieuwerpoort, te Duunkerke met ere commissie, dat hem de goede lieden ghereet soude maken jeghen de Noormans te vaerne, up dat mere eneghe wiste up mijns heeren stroom...". Brussel, Alg. Rijksarchief, Rekenkamer van Vl. en Brab., rolrekening nr 1544, rekening van Jacomaerd van den Vale, baljuw van Nieuwpoort, over het ambtstermijn 9 mei - 29 september 1379. 
digers van de Engelse koning werden in 1380 voorgezet ${ }^{115}$, maar tot een definitieve overeenkomst, die de bestaande moeilijkheden zou opheffen en de hangende kwesties zou regelen, kwam het vooralsnog niet ${ }^{116}$. In Frankrijk stierf inderdaad Koning Karel $\mathrm{V}$ en beklom de minderjarige Karel VI de troon, terwijl in Vlaanderen en Engeland sociale troebelen uitbraken. In dergelijke omstandigheden kon er voorlopig niet verder aan ernstige onderhandelingen worden gedacht.

We bedanken de heren conservators en de diensten van de „Archives départementales du Nord" te Rijsel voor de fotokopieën, die we van de hier bestudeerde oorkonden mochten ontvangen.

(115) Zie voetnoot 26.

(116) Eerst op 28 november 1387 wisten de Leden van Vlaanderen, na besprekingen te Calais, met de Engelsen tot een handelsovereenkomst te geraken. W. Söchting, Die Beziebungen zwischen Flandern und England am Ende des 14. Jabrhunderts (in: Historische Vierteljahrschrift, herausgegeben von Dr. E. Brandenburg, XXIV Jahrgang, 1927-1929, blz. 182-198), blz. 189 en 191, bewijsstuk nr I. E. Varenbergh, a.w., blz. 493. 


\section{B IJ L A G E N}

Aanhef van bet klad, dienend voor bet opstellen van bet verslag van de besprekingen tussen de commissarissen van de koning van Engeland en de graaf van Vlaanderen nopens de klachten van bun respectievelijke onderdanen over de van elkaar geleden schade en nopens de wijze van schadeloosstelling of van verder onderzoek.

\section{Calais, 10 juli 1378}

Rijsel, Archives départementales du Nord, B 515 / 18778. Op papier.

Dit klad bevat alleen de opsomming van de antwoorden op de ingediende klachten. De aanhef zelf is onvolledig wegens de beschadiging van het papier, maar ze kan gedeeltelijk door middel van de gegevens uit de slottekst hersteld worden. Ze geeft een idee van wat de inleiding van het definitief verslag, volgend in bijlage II, maar waarvan het papier nog meer beschadigd is, kan geweest zijn. De mogelijk te veronderstellen tekst staat tussen haakjes, terwijl we de eigenlijke tekst met het klad van de antwoorden weglaten, aangezien die in de volgende bijlage te vinden is.

(Nous) ... (Hue Calverley, capitain de Calais, ... Hue de Sanct Gr)ave, Bernard Brokas, capitain dou chastel de Calais, chevaliers, Wautier Scharloo, doien de Saint Martin (de Londers, Esmond de Haelstede et Richard Woedehale, conseillers et commissaires dou Roy d Engleterre. Et maistre Guillaume Ver)maechtenzone, doien de 1 eglise Saint Donas de Bruges, Jehan Vilain (chevalier et Jehan de la Faucille, escuier, conseilliers et commissaires en ceste partie dou) conte de Flandres, faisons savoir a tous et cognissons par ceste ... (entre) les gens et subges doudit Roy d une part. Et les gens et subges (doudit conte de Flandres $d$ autre part) ... (bailliet) oultre par escript de plusieurs biens et marchandises prises et (robees) ... et doit faire $d$ une part et $d$ autre par le traitie et accort fait par entre ... a Bruges ou mois de may (darrain) passe. Nous, par vertu dou pooir ensemble a nous donne, sommes accorde et en avons fait faire restitution ... (claire)menct peut apparoir par 2 rolles de papier scellees et placquies de nos seels, dont cescune partie de ... en avons 1 par devers nous ou les dites complaintes sont... Et par la maniere que le dit rolle contient, nous sommes tenu d aler et proceder avant pour parfaire et paraccomplir toutes le choses contenus en ycelly $d$ un coste et $d$ autre en bonne foy sans fraude et melangien. Et en tesmoing de ce nous avons mis en placquiet nos seels a ceste presente cedule, faite et donne a Calais le $10 \mathrm{e}$ jour de jullet 1 an de grace 1378 .

$\mathrm{C}$ est ce qu accorde et restitue est des complaintes des biens $d$ un coste et $\mathrm{d}$ autre.

Premiers, sur le premiere complainte touchant le herenc. Restitution est faite dou dit herenc et pisson... (etc.) 
Verslag van de besprekingen tussen de commissarissen van de koning van Engeland en die van de graaf van Vlaanderen nopens de klachten van bun respectievelijke onderdanen over de van elkaar geleden schade en nopens de wijze van schadeloosstelling of van verder onderzoek en dit in de vorm van aanklachten, elk gevolgd door een antwoord.

Calais, 10 juli 1378

Rijsel, Archives départementales du Nord, B515/18.288. Papieren rol, met onderaan de brokstukken van een achttal zegels, die erop geplakt waren.

Het bovenste gedeelte van de rol met de erop geschreven tekst ontbreekt als gevolg van beschadiging. De tekst in zijn geheel bestaat, naast een aanhef of inleiding en een slot, uit vier reeksen klachten, namelijk drie uitgaande van Vlamingen en een van Engelsen. Ten behoeve van de verwijzingen in voetnoot laten we deze klachten door een nummering voorafgaan. Van de aanhef bleven maar enkele zinsneden over. Heel waarschijnlijk kwam ze grotendeels overeen met de inleiding van het klad van de antwoorden op de aanklachten, hierboven afgedrukt in bijlage I. Ze verwees inderdaad, voor zover we dit kunnen nagaan, eveneens naar de reeds vroeger, in mei te Brugge gehouden conferentie. Tussen haakjes plaatsen we de in de marge van de rol aangebrachte aantekeningen, opmerkingen of antwoorden.

... coste et $d$ autre a Bruges ou ... fait restitution par les ... le 10 me jour de juillet 1 an dessus dit, ensi que s ensient.

(1) Premiers, se complaingent Jehan le Kien de Noefpoort, Jehan dou Four et Berthelmieu le Grave de Dunkerke, Baudewin le Jovene de Broucborch et Clais le Maistre de Berghes, de 48 last de herens kakes et soirs ou plus et une quantitie de pisson sale, que Guillaumes Sexton et ses complices prirent et roberent sur mer hors de 3 neifs a euls appartenans, dont restitution aucune $\mathrm{n}$ a este faite selon la dite ordenance, ja soit ce qu il aient pousievy a leur grant frait et domage si comme il dient.

- Restitution est faite dou dit herenc et pisson as dessus nommes complaingans par Guillaume Sexton pour lui et ses complices, pour la value des biens, qu il furent vendu de la somme de 705 nobles, dont parties a paye presentement et le sourplus s est oblige a payer a 2 termes, ainsi que la lettre de 1 obligation contient.

(2) Item, se complaingent Jehan Kant, Jehan Pontieu et Gilles Joerdaen, bourgois de Dunkerke, comment il avoient estoffe 1 cogghe, dont Baudouin Lottin fu maistres, pour sigler en la Baie, hors dou quel cogghe furent pris ankres, cables et vitailles et pluseurs personnes par 7 barges 
d Engleterre, le veille de Penthecouste darrain passe, de la flote d amiral dou conte d Arondel, entre Wicht et Porlant, et ne scet on ou la cogghe est devenu et se li maistres, qui fu pris, est en vie ou non, des quels biens restitution n est faite, si comme il dient.

- Sur ce est accorde pour tant que les biens, dont la dite complainte fait mention, furent pris par la flote de 1 amiral dou conte d Arondel, $\mathrm{d}$ en escripre au dit conte de par le consel d Engleterre, affin que restitution en soit faite as dis complaingans.

(3) Item, se plaint Jehan de le Pale, bourgois de Bruges, pour lui et ses complices de 900 heus de ble a le mesure de Flandres, qui montent a le mesure d Engleterre 600 quartiers ou environ, pris et arrestes par le capitain de Calais, dont on leur a restitue 306 quartiers, pour les quels ils paierent as laboureurs de la mesure et pour autres coustainges 100 ecus de Flandres et le remanant dou ble est a restituer, si comme il dient.

- Restitution en est faite, tant en ble comme en argent, a ceuls de 1 Escluse, de 650 heus de ble. Et quant as autres 200, que Jehan de le Pale disoit a lui appartenir, les quels le capitain de Calais a pris comme biens de Franchois par une information qu il en fist, pourtant que monseigneur de Flandres escripst au dit capitain et tesmoinga par ses lettres que 850 heus dou dit ble appartenoit a ceuls de 1 Escluse et de Bruges et que son tesmoingage fait a croire par deseure la dite information, il est ordene par les 2 consauls que le capitain nantira et mettra en main sequestre la value des dis 200 hues par ceste condition, qu il en escripra a monseigneur de Flandres, ce qu il en a fait. Et ce que monseigneur en ordonnera, se kerkier s en voelt, soit de delivrer le dit ble au dit Jehan ou non, ce sera tenu. Et se monseigneur de Flandres ne s en voelt kerkier, les 2 consauls en ordeneront a le premier journee, appeles les 3 maistres des neifs, qui le dit ble chargierent et le partie.

(4) Item, se complaint Jehan Uuten Brouke, bourgois de Bruges, de 10 lasts de cendres, 8 pieches de plonc, 104 entre pipes et tonniaulx enbotes, qui cousterent de premier achat $47 \mathrm{lb}$. gr., pris par Jehan Moer de Romenay et Jacque Dyne d Yde, dont restitution n est faite, ia soit qu il ait poursievy par 18 sepmaines, en la quelle poursieute il a despendu 60 nobles, si comme il dist.

- Restitution est faite des dis biens au dit complaingant pour la value, qu il furent vendu, de la somme de 30 livres de gros monnaie de Flandres, des quels le consel d Engleterre a promis a lui faire payer dedens dimenche prochain en $15 \mathrm{e}$ jours.

(5) Item, se complaint Jehan Bloume, bourgois de 1 Escluse, de 24 tonniauls de crasse, appelle sain de malemort, chargies en la neif Jaquemart le Witte, bourgois de Dunckerke, le quelle neif les Engles prirent et menerent a Calais et detiennent encores le dit sain, si en demande restitution.

- Restitution est faite au dit complaingant pour la value dou sain de la somme de 15 livres d estrelins, a le prisie de 2 marchans a ce connues. 
(6) Item, demande le dit Jehan a avoir restitution de 16 muys de ble perchiers a lui appartenans, chargies en la nef Jehan fil Gherart de Noefpoort, le quel ble les Angles ont pris, dont il demande restitution.

- Accorde en sont le capitain de Calais et Jehan Bloume entre euls.

Et de ces poins dessus escrips se doit faire restitution presentement a Calais selon le traitie et accort dessus dis.

(7) Item, se complaint Jehan le Riethane, bourgois dou Dam, pour lui et ses complices, de 66 tonniauls de vin, les quels furent achetees 600 frans, que le dit Jehan envoia en la Rochele et furent chatgies en la nief Jehan le $\mathrm{Mol}$ de Biervliet, les quels furent pris a Plainemue en Engleterre, dont nulle restitution $\mathrm{n}$ est faite

(Les parties sont $d$ accort)

(8) Item, se complaint Jehan le Mol de Biervliet, d une neif, qui li fu prise a Playnemue, et 64 tonniauls de vin a lui appartenans. Item, 18 tonniauls appartenans a Jehan Pinchemer. Item, 5 tonniauls et pipe appartenans a Godevart de 1 Escluse, chargies tous les dis vins en la dite neif, les quels parceuls valoient 700 livres de gros, dont aucune restitution n est faite, si comme il dient.

(Les parties sont $d$ accort)

(9) Item, se complaint Wautier Goederic, bourgois dou Dam, de 68 tonniauls de vin a lui appartenans. Item, 5 tonniauls appartenans a Jehan de Tournay et 5 tonniauls appartenans a 1 marchand de Gand. Et 24 tonniauls appartenans a Pieter Plume de Monekerede, tout chargies en une neif, qui fu a Jaqueme Reylof, et une pipe de florat chargie en une autre neif, prises des 7 neifs d Engleterre et menes a Plainemude, dont restitution n est faite, ja soit qu il aient fait poursieute par longtemps par certaines personnes a ce commis, des quelles personnes il doubtent de leur vie, pour les forches, manaches, outrages qu on leur fait, si comme il dient.

(Les parties sont $d$ accort)

(10) Item, se plaingent Pierre fil Gautier et Kerstiaen fil Pieter, de 9 tonniauls et une pipe de vin et leur harnas, qu il avoient en leur neif, pris en Engleterre a Dertmude, et de la voiture de 20 tonniauls de vin, qu on leur detient et pooit le harnas de leur neif valoir 16 livres d estrelinz, dont restitution n est faite, si comme il dient.

(Les parties sont $d$ accort)

(11) Item, se complaint Jehan le Cupre, de $1 \frac{1}{2}$ tonnial de vin qu il li fu pris en la neif Pierre fil Wautier de 1 Escluse.

(Il est accorde) 
(12) Item, se complaint Pierre fil le Backere, bourgois de 1 Escluse, de 3 tonniauls de vin chargies en un cogghe, dou quel estoit maistre Clais Heins de 1 Escluse, pris par les Engles a Plainemude, dont il demande restitution.

(D accort)

(13) Item, se complaint Henry Bast, bourgois de 1 Escluse, d'un heulc, dont estoit maistres Clais Porre de Duerdrecht, le quel les barges et neifs de Bayonne prirent avoec les apparauls, 1 affreture et les biens et marchandises estans ou dit heulc, et le menerent a Playnemude, dont le quarte partie dou tout appartenoit au dit Henry, montant a la valeur de 50 livres de gros, dont nulle restitution est faite.

(D accort)

Et les 7 complaintes dessus dites sont des biens et marchandises prises es 7 neifs, qui furent pris a Playnemude, dont restitution se doit faire selon 1 accort dessus dit.

Sur les 7 complaintes des 7 neifs dessus touchant le consel d Engleterre a dit en bonne foy, qu avant leur departement darrainement d Engleterre, le Roy d Engleterre avoit ordene et envoye certains commissaires, est assavoir 4 chevaliers et 1 clerc de 1 eskekier, as lieus ou les dites neifs et biens furent pris et arrestes, pour faire faire restitution as subges monseigneur de Flandres, des biens qu il trouverent encores desoubs les preneurs et detenteurs. Et $s$ aucuns biens en sont dissipe, vendu et aliene, qu il enquerront les preneurs et les constraindront par prise de corps et vendue et explectation de leurs biens, affin de restitution des dis biens, et les feront plainement restituer en value, si avant que raison sera le plus brief qu il porront bonnement.

Et se parfait $n$ estoit dedens le journee ci apres declarie accordee a tenir a Graveninghes par les 2 consauls, il se devra parfaire a la dite journee sans autre delay.

Et est 1 entente dou consel monseigneur de Flandres et en font especiale reservation que, en cas que plus de biens et marchandises prises es dites 7 neifs fussent trouves a remparer et restituer, dont nulle mention est faite par dessus, et les marchans de Flandres en fesissent aucune poursieute ci apres, que reparation et restitution se fera tant des neifs, comme des biens, dont poursieute se feroit, ainsi qu il est accorde.

Chi apres s ensievent autres complaintes, faites depuis 2 ans encha, de biens prises par les Engles sur les marchans de Flandres, dont restitution se doit faire pareillement.

(14) Premiers, se complaingent le vesve et les hoirs Everard Goederic, Guillaumes de Cleyhem et Morissis de Crayenbrouc, bourgois de Bruges, de 1.930 pieches de fighes. Item, 900 pieches de roysins. Item, 10 pipes et 2 tonniauls de tainte. Item, 3 pipes de vin blans. Item, 10 pipes de sain 
de lisse. Item, une pipe de miel. Item, 140 quirs secs. Item, 50 quirs vers. Item, 5 bales de sieu. Item, 5 bales de chire. Item, 18 petis fraielles de fighes. Item, 13 petis fraiels de roysins signees de 2 markes. Item, 5 escrins, es quelles estoient 4 estables $d$ argent. Item, en argent d Espainge noir et blanc, la somme de 32 livres de gros monnoie de Flandres. Item, leurs draps, papiers, comptes, leurs lettres et une lettre de 80 frans, qui estoient prestes au maistre de la neif sur son fret, les quels biens il firent achater et chargier en Espainge en une nef d Espaigne, de Fronteraby, pour mener vers Flandres, les quels biens furent pris sur mer par 2 neifs d Engleterre, par messires Raoul de Ferrieres et Esmond Rose, avoec 2 valles estans sur les dis biens, et furent mene a Playnemude, dont 1 un des 2 valles est mort et 1 autre demoura en prison 4 mois ou plus. Et $\mathrm{n}$ ont peu avoir delivrance de leur biens, ne valles, ja soit ce que monseigneur de Flandres en a plusieurs fois escript et qu il avoient lettres patentes dou dit monseigneur de Flandres et de la ville de Bruges de tesmoingage, que les dis biens estoient a euls et non a autrui et qu il en eut fait caucion soffisant, qu il estoient a euls.

- Sur ce est ordene que messires Raoul de Ferrieres et Esmont Rose, preneurs et detenteurs des dis biens, seront mande devant le consel d Engleterre dedens le dite journee pour euls oir et faire respondre sur la dite complaine et en faire acquit, droit et restitution a la dite journee, si avant qu il appartendra, et de ce se sont chargie les commissaires dou dit Roy.

(15) Item, se deulent monseigneur de Flandres et ceuls de 1 Escluse, remonstrant au consel d Engleterre, comment Willaumes Goossin, bourgois de 1 Escluse, se tenoit et gisoit a toute sa nef a Develinghe en Hirlande, leur il avoit deschargiet sa charge des biens, qu il avoit amenes, et recue 1 affreture des dis biens, la vinrent siglant une neif de Brestau et une autre de Vaelmude avoec leurs boots, biens pourveus et garnis, et de fait avise et de nuyt. Les compaigons des dites 2 nefs se misent en la nef dou dit Guillaume et le murdrirent et tous ses compaigons, excepte 1, qui a mort fu navres. Et ce fait, prirent la dite nef, 1 argent de 1 affretement, les apparauls et tout ce qui estoit en ycelle, dont autreffois grant poursiente a este faite en Engleterre par devers le Roy, dont riens $n$ a este restitue, ne rempare.

- Sur ce est accorde d enquerir la verite de par le Roy d Engleterre et en faire faire restitution et amende a la journee, si avant qu il appartendra.

(16) Item, demande Pieter Zoete, bourgois de 1 Escluse, a avoir restitution des Engles de 3 last de herens, qui furent pris par les Engles, dont il a fait caution a la court de Flandres de 24 livres de gros, que les dis herens estoient a lui, ainsi qu il dist.

- Sur ce est accorde, qu il declare qui le herenc prist et en quel lieu et on en respondera a la dite journee. 
(17) Item, se complaingent monseigneur de Flandres et ceuls de le ville d Oostende, comment 3 barges d Engleterre 1 une de Londres, 1 autre de Jork et le tierche de Lynne, ont tue et murdri sur mer Pierre Bone $\mathrm{d}$ Oostende, maistre d une neif appele corvere, et 18 compaignons et 2 petis garchons en ycelle estans, euls partans de 1 Escluse pour sigler vers Sconen en fait de marchandise, et prirent la dite nef chargie de sel avoec tous ses apparauls, qui bien valoient 180 livres de gros, sans aucune cause et sans ce qu il eussent en riens meffait envers euls, prisent aussi la vitaille et tout ce qui y estoit et le menerent la ou il leur pleut, dont les vesves et enfans d iceuls mariniers ainsi murdris sont dou tout desole et destruit. Si demandent que restitution et amende en soit fais, ainsi qu il appartient.

- Sur ce est accorde que le consel d Engleterre $s$ infourmera sur la dite complainte et en fera restitution et amende a la dite journee, si avant que de raison appartenra.

(18) Item, se complaint Hector de Mulhem, bourgois de Bruges, et demande a avoir restitution de 12 lasts de herens cakes, chargies en une nef appelle Crucemberch, dont estoit maistres Jehan Noits de le Neuse, le quelle devoit sigler a Rouen en Normandie en bonne marchandise pour faire son proffit, le quel herent fu prins par messire Thumas de Persy et mene a Winkelsee, dont aucune restitution $\mathrm{n}$ a este faite, ja soit ce que monseigneur de Flandres en ait escript, si comme il dist.

- Restitution en est accordee a faire a la dite journee.

*

Chi apres s ensievent les complaintes des subges dou Roy d Engleterre, qu il baillerent oultre es commissaires et deputes dou dit Roy a le journee, tenue a Calais par les deputes dessus dis et les deputes monseigneur de Flandres au jour et an dessus dis, dont restitution se doit faire par la maniere qu il appartendra comme dessus.

(19) Premiers, se complaingent Jehan Edrop, vivetier de Londres, et autres marchans d Engleterre, ses complices, de Guy Quidiel, maronnier de 1 Escluse, de ce que les dis marchans avoient affrete la neif dou dit Guy de ammener de Bourdeauls a Londres, a sa droite descharge, 160 tonneauls de vin a euls appartenans, par convenance telle que le dit Guy se devoit tenir en la compangie de la flote des Engles et $\mathrm{d}$ euls non departir, iusques a tant qu il fust venus a sa droite descharge a Londres et, ce non obstant, il s en ala vers les ennemis de sa volente et par malice, sans constrainte aucune, et abandonna les dis biens as ennemis, ainsi qu il dient. Si en demande restitution iusques a la value de $640 \mathrm{lb}$. d esterlins.

- Sur ce est accorde que le consel de Flandres manderont et feront venir a la dite journee Jaqueme Crakebeen, qui part avoit en la neif, et le maistre de la nef pour respondre sur la dite complainte et, euls oys, on en fera faire droit et raison, siavant qu il appartendra. 
(20) Item, se complaint Jehan Bentham, Englois, de Matheus f.Clais, amiral de Flandres, de ce que le dit Matheus prist en Baye de Tristram en Bretainge 1 cogge, appelle Christofre, chargie de sel, de vins de Gasschoinge et autres marchandises estans en ycelly, appartenans au dit Jehan, montant le domage iusques a la value de $400 \mathrm{lb}$. estrelins, sans autres cous et domages, qu il a soustenus pour celle cause depuis la dite prise, ainsi qu il dist, dont il demande a avoir restitution.

- Sur ce est accorde que monseigneur de Flandres donra 1 sauf conduit au dit Jehan, tant qu en lui est pour venir en Flandres et pour suievir devant monseigneur de Flandres et son consel le dite complainte a 1 encontre Matheus f. Clais et ses complices et monseigneur de Flandres et son consel lui en feront faire droit et raison, siavant qu il appartendra, dedens la dite journee. Et se fait $n$ estoit, que une fin s en fera a la dite. journee par les 2 consaulz.

(D accort)

(21) Item se complaint Thomas Sir, marchant de Bristauwe, d un maistre maronnier del Escluse, de ce qu il mena a 1 Escluse certaine quantite de vins, qu il avoit affrete de mener a Londres, de Lucembonne et de Portingale, et non ailleurs, si comme il dist, c est assavoir 25 tonniauls de vin, dont il demande restitution.

- On a donne entendre as 2 consaux que le dit Thumas et le maistre de la neif sont $d$ accort et que les vins sont delivres et partant $\mathrm{n}$ en peuvent autrement ordener, mais en cas qu il n estoient $d$ accort, qu on en fera une fin a la dite journee.

- Le maistre a a non Pieter Stocker.

(Note, de mander la partie, qu il ne sont point d'accort)

(22) Item, se complaingent Robert Blount et Symon Wilhmet, comment deus nefs de Flandres prirent et roberent sur une nef, chargie de poisson et d artellerie a la value de 300 mars, et occirent 12 des mariniers, qui estoient en la dite neif, dont il demandent a avoir restitution et amende, le quel fait fu fait par ceuls d Oostende le samedi en le sepmaine de Pasques et $y$ avoit une neif nouvelle a tout un voile, qui avoit 1 drap rouge de long, si comme le consel d Engleterre sont infourme.

- Sur ce est ordene que le consel de Flandres $s$ infourmera sur la dite complainte a Oostende et la il appartendra et en respondront a la journee et en feront faire restitution et amende, siavant qu il appartendra.

(23) Item, se complaint Philippot Travers, de ce qu on a fait arrester a 1 Escluse 3 rodes de vin rynois et demi et 8 sextiers, prisie le rode 13 lb. gros, dou premier achat. Item, 5 botes de vin douche, prisie le bote a 32 escus, avoec la coustume, avoec 1 affreitement des dis vins, montant 18 nobles, sans autres cous et domages, dont il demande a avoir restitution, qui montent a la value de 59 livres de gros, sans les domages.

- Le capitain de Calais, a qui les dis vins et biens appartenoient, et Jehan Bloume, ou nom de ceus de 1 Escluse, sont accorde entre euls par telle maniere que les 200 heus de ble, que le dit capitain doit de rest a 
ceuls de 1 Escluse, sont en rabat des dis vins. Et en deseur ce, le capitain doit avoir 31 livres $16 \mathrm{~s}$. estrelins, dont Jehan Bloume en fait paiement pour ceuls de 1 Escluse, $15 \mathrm{lb}$. d estrelinz, qu il doit avoir de son sain et le remanant doit on paier au dit capitain 15 jours devant la Toussains prochain venant, dont messire Jehan Vilain et Jehan de la Faucille ont respondu au dit capitain, a le pryere de Jehan Bloume, le quel Jehan Bloume les a enconvent deu des domages devant les 2 consauls. Et se aussi que par monseigneur de Flandres ou par les 2 consauls soit ordene que le dit capitain restitue les 200 heus de ble au dit Jehan de le Pale et ses complices, ce sera en rabat de ce qu on li doit.

- Restitution en est faite.

(24) Item, se complaingent Nicholas Brembre et Jehan Philippot, marchans de Londres, de Wouter Jans zone, marinier de 1 Escluse, de ce que le dit Wouter Jans zone avoit affrete 20 sacs de laines pour les avoir amene a 1 estaple a Calais ou mois de fevrier darrain passe, le quel arriva a sa miete a Dunkerke, et depuis de sa volente s en parti et mena les dites laynes en Normandie, ou il vendi les dites laynes, sans le sceu des dis marchans, en grant domage d euls, iusques a la somme de 450 mars d estrelins, et estoit la dite neif a Jehan Belle de 1 Escluse, qui le dit Wouter Jans zone en fist maistre ou au mains avoit partie $d$ ycelle, dont il demandent a avoir restitution.

- Sur ce est accorde que le consel de Flandres manderont devant euls dedens la journee Jehan Belle de 1 Escluse, a qui la dite nef estoit et les maronniers, qui furent en la nef, pour respondre sur la dite complainte et le consel infourmer dou fait et en fera on droit et restitution a la journee, si avant qu il apartendra de raison.

(On mandera Jehan Belle)

(25) Item, se complaingent Robert Pilche, Richart FFlete et Jehan Horeweder, seingneurs d une barge de Ploumith, de Matheus f. Clais, amiral de Flandres, et ses complices, de ce que le dit Matheus et ses complices prirent d euls une nef de 180, chargie d avoir de pois d Espainge, ennemis du Roy d Engleterre, le quelle avoit este en leur poissance 4 jours et 4 nuyts. Item, prirent 1 crayer de Ploumith le meisme jour et tuerent 21 personnes, qui estoient dedens, les quels biens et neifs valoient bien 2.000 livres d estrelins, sans le domage et perte de personnes, ainsi qu il dient, dont il demandent a avoir restitution et amende.

- Sur ce est accorde que on mandera devant le consel de Flandres Mathis Clais zone et ses complices dedens la dite journee pour respondre sur la complainte. Et a la journee on en fera siavant qu il appartendra.

(On mandera Mathis f.Clais)

(26) Item, se complaint Thumas Gindalier, cytain de Londres, dou bailliu de 1 iauwe a 1 Escluse, de ce que le dit bailliu arresta au dehors dou havene de 1 Escluse 85 dousaines de diverses draps, costumes et cokettes, les quels le dit Thumas avoit affrete en 1 cogghe de Dankt de Pruys pour aler et sigler en Prusse, le quel cogghe par tempeste de mer arriva a. 
1 Escluse, pour le delivrance des quelles draps il a poursievi monseigneur de Flandres pluseurs fois par lettres dou Roy d Engleterre, des quels il n a peu avoir delivrance, si comme il dist, dont il demande a avoir restitution.

- Sur ce est accorde que le consel de Flandres en parleront a monseigneur de Flandres pour en respondre a la journee.

(27) Item, se complaint Richard de Preston dit Roille, de 24 draps et demi d Engleterre de divers coleurs et 9 blancs manteuls d Irlande, arrestes et pris a 1 Escluse par le bailliu de 1 yauwe, les quels draps estoient affrete pour venir a Calais et arriverent a 1 Escluse par tempeste de mer et ne peut avoir restitue, ne delivre les dis draps, ia soit ce qu il 1 ait poursievi. Si en demande a avoir restitution.

- Sur ce est ordene que le consel de Flandres en parleront a monseigneur de Flandres pour en respondre a la dite journee.

Et est assavoir que une journee est prise et accordee a tenir par les 2 consauls dessus nommes a Graveninghes le jour sainte Cateline prochain venant, a estre as hosteus pour accomplir et parfaire toutes choses en la maniere que dessus est ordene et accorde.

Et en tesmoing de ce que les choses dessus dites sont accordees, ordenees et restituees par la maniere que dessus est escript et expresse sur cescune complainte par les 2 consauls et commissaires, c est assavoir messire Hue Calvylay, capitain de Calais, messire Hue de Sanctgrave, messire Bernard de Brokas, capitain dou chastel de Calais, chevaliers, maistre Wautier Scharloo, doien de Saint Martin de Londres, Esmont de Haelstede et Richart Woedehale, conselliers et commissaires dou Roy d Engleterre. Et maistre Guillaume Vernaechten zone, doien de Saint Donas de Bruges, messire Jehan Vilain, chevalier, et Jehan de la Faucille, escuier, conselliers et commissaires en ceste partie dou dit monseigneur de Flandres, les dis commissaires ont mis et plakie leurs seels a cest present rolle.

Ce fu fait et accorde a Calais le 10e jour de jullet 1 an 1378.

III

Lijst met de opsomming van de klachten geformuleerd door de burgers van Sluis tegen de Engelsen, van wie zij schade op zee ondervonden badden, waarvoor zij nog steeds geen genoegdoening ontvangen mochten, niettegenstaande bun berbald aandringen bij de raad toen opgericht door de koning van Engeland en de graaf van Vlaanderen voor de regeling van de bestaande gescbillen.

26 mei 1379 of kort ervoor

Rijsel, Archives départementales du Nord, B 515 / 18.286. Papieren rol.

De klachten laten we door een nummering voorafgaan.

In paragraaf 1 wordt verwezen naar de conferentie te Brugge. 
Che sont les plaintez des bourgoys del Escluse en Flandrez, faites a cause des dampmages, qu il ont eu des gentz du Roy d Engleterre, les quels il ont poursievi long tamps a par devant les seigneurs du conseil du Roy avantdit et de notre tres redoubte seigneur, monseigneur le conte de Flandrez, dont ancoire il $\mathrm{n}$ ont point eu fin ne determination.

(1) Primirement, demonstrent il par devant les seigneurs du conseil des seigneurs avantdiz, estanz au traitiet presentement a Brugez, par especial Jehan de Cleyem, fil Henri, et Philippes, ses frerez, que ou tamps passe il heurent chargiet en une cogue, dont estoit maistrez Martin Lam, 21 tonneaux de vin appartenantz a eaulx duex et a nul aultre, les quels il avoient empense de faire ammener a l'aide de dieu de la Rochele envers Flandres. Et en venant ainsi par mer devant Goudstard, si fu la dite cogue prise par forche des genz du Roy avantdit, appellez Joonkin Heston et Ritchard Herri, et aultrez leur complicez, envoyes du port de Dartmue. Et combien que de puis la dite prise faite par information suffisante, tant par lettres patentez, saielleez dou saiel de la ville del Escluse, comme du saiel notre dit redoubte seigneur, monseigneur le conte de Flandres, infixees par mi ycellez, si fu demonstre au Roy devant nomme et les seigneurs de son conseil et a se requeste mesmez, que li dit 21 tonnel de vin appartenoient az dis plainganz et che avant che que primirement entre les dis seigneurs fu ordene, que li subget monseigneur de Flandres devoient passer paisiblement entre lez gentz du Roy par caucion et par lettres de le ville, dont il estoient aprouvees par les lettres du prince devant nomme, ainsi que de puis aultre fois si fu ordene. Nientmainz se ne poerent li dit plaingant onques de puis avoir restitution de luer dit dampmage, non obstant les lettres du commandement adrechanz de par le Roy et envoyez de par lui par son sergant $d$ armez a ses gentz de Dartemue.

Restitution des diz vinz leur fu faite sanz aucun contredit et chou par le grant pryere et information que monseigneur de Flandres en fist au Roy par les dis plaingantz. Ains heurent li dit Joonkin Ritchard et leur complicez si grant port d encoste le Roy, du seigneur de Latemer et d aultrez, que li dit Philippe et ses compainz envoijes avoec lui de par son dit frere pour ceste besoinge poursievir pres, euissent estez tues et mourdri, quant il avoient despendu a chesti cause, oultre le dit principal, la somme de 30 livres de gros et qu il avoient cause de laisier la cause vage et a determiner pour le grant peril de leur corps et ainsi a elle demoree jusquez a orez, combien que touz jours on la remettra a touz traitiez. Montanz le dit principal et despenz a 100 et 30 livres de gros et plus.

(2) Item, se demonstrent le dit Jehan de Cleyem et Riquaerd, ses frerez, qu il et leur compaingnons, bourgoys del Escluse, environ le saint Martin derrain passe, chargierent en la barge monseigneur de Flandres, dont estoit maistre Romboud Arnoudzuene, 19 last de herencz sorez, dont il firent caucion en la maniere coustumee et par lettres de la dite ville, aprouvees de par mon dit seigneur le conte. Sur les quels biens il fu envoyes li dit Riquardz et ent chargies le dit maistre de la barge, le quel 
hereng, armurez, appartenantz as corps du dit Riquard, maistre et maronierz de la dite barge, furent pris sur terre en Engleterre et en la conte de Harondele et pour lui (ou port de Chicestre) (a), li quels contez tenoit en prison le dit maistre et Riquard de Cleyem par 1 espace de 15 jours ou de plus. Et non obstant que de puis monseigneur de Flandres, oultre ses ditez lettres, escrifist aultrefoys au Roy et a son conseil pour yceaulx, a fin que la dite barge a tout la dite charge a eaulx appartenantz, non fourfaite selonc le traitie, se ne poerent li dit plaingant par les seigneurs dou conseil du Roy avoir adrechement de leur dampnage, Ains despendi le dit Riquard, sanz ent avoir declaration, le valour de 20 nobles $\mathrm{d}$ or, montant ensamble le dit principal et despenz a la somme de 100 et 32 livres de gros.

(3) Item, se demonstre Adrian Tant, bourgoys de 1 Escluse, que les gens du Roy d Engleterre, assavoir est Stevin Favri de Hanthome et ses complices d Engleterre, prirent hors d une neif (passe 9 semainez ou environ) (b) un an passe ou environ, 22 last de blancz herencz, 4 last de herencz sorz et de 200 et 9 francz d or en argent sec, la quelle neif, herencz et argent appartenantz au dit plaingant et a nul aultre, a toute la dite neif et les appareaulx et contenu d ycelle, dont il mesmez en estoit maistrez, lui fu prise sur la trade en alant de Flandrez envers la Rochelle (ou ailleeurs) (c) dou dit Stevin et ses complicez et mene a (Hamthon) (d) Plainmue ou li dit maistre fus mis a gihine et a grant martyre, sanz cause et raison, ainsi qu il apparu depuis par 1 informacion, qu il en fist au conseil du Roy. Nentmainz si en eut onques restitution de se dampmage, forz la dite neif, 18 tonnaulx de blanc hereng et 18 meses de herencz sorz, montanz le remanant de sa dite perte a la somme de 2.500 escus, selonc 1 estimation faite par devant le conseil du Roy, dont li Roy bailla ses lettrez adrechantz a sez dites gentz, mes onques en recue maille, ne denier le dit plaingant.

(4) Item, si eut en la dite neif Ryquaerd Cloud, bourgois del Escluze, une pipe et un baril de batrie, montant a la somme de 42 livres de groz ou environ, laquelle batrie se fu mise a 1 ostel Jehan Pollemont, demorant a Hantonne. Requiert d ent a ravoir restitution.

(5) Item, ancoire se plaint le dit Adrian des gentz du Roy d'Engleterre, que depuis un moys encha il lui prirent hors $\mathrm{d}$ une cogue, appartenant a lui entirement, dont estoit maistrez Guillaumes Pres, 32 lastz et 3 baris de blanc herencz et une pipe $d$ ole et avoec che en vitaille et en aultrez besoingez, appartenanz tout a lui et a nul aultre, dont il fist bonne caucion, comme dessus, la valour de 15 livres de groz, contant ensamble 1.800 escus, cascun compte pour 24 gros de Flandrez, et fu pris la dite

(a) Bijgevoegd tussen de regels.

(b) Doorgestreept, wat er op wijst, dat de klacht reeds het jaar voordien een eerste maal ingediend geworden was.

(c) Bijgevoegd tussen de regels.

(d) Doorgestreept. 
neif a touz les dis bienz devant Calays, de Jaque Pieters, maistre de la barge appartenantz a messire Huge de Calvillay, le quels Jaques mist a gehine le marchant envoyet sur les diz bienz, appelez Jehan Maersensuene, bourgoys de Brugez, afin qu il dist par forche de gehine que lez dites derrees fuissent as anemis dou Roy d Engleterre.

(6) Item, se demonstrent Florens de le Bourch et Pieter Zoete, bourgoys de 1 Escluse, comment, passe 3 semainez environ, les gentz du Roy d Engleterre, assavoir est Symekin Pavez de Douvre, leur prist par forche une neif, dont maistrez estoit Pieter le Mulgemakere, et 13 last de herencz blancz tout a eaulx appartenantz et a nul aultre, les quels il avoient chargiez pour mener en la Somme ou ailleurz pour leur profyt. Et, venant devant Zandgate, venoit li dit Symekin a tout ses complicez et le mena avoec lui a Douvre et le detienent illequez gisant et $n$ en poerent onques depuis rienz avoir, ne de li dite neif a tous ses apparaux, ne des ditz 13 lest de hierens, tout appartenans a eaux deux plaignanz et a nul autre, dont il eurent lettrez de caution en la maniere accoustumee selon le derrain traitiet.

(7) (Item, ancoire demonstre le dit Pieter Zoete, comment, ores a un an ou environ, il avoit chargiet en une neif, dont estoit maistre Jehan Willard, trois last de herencz, appartenantz a lui solement et a nul aultre, pour ycheux mener en Seyne, et venant entre les Kiefz, venoit une bardse, appartenant au seigneur de Latemer, et prirent la dite neif et bienz et $1 \mathrm{am}$ menerent a Londrez et le quel hereng le dit sire de Latemer eut et tenoit et ancoire detient pour lui, non obstant lettres de caucion, que le dit Pietre Zoete en avoit fait a monseigneur de Flandres (par le information) (e) des lettres d esquevins de la ville del Escluse, les quellez on trouveroit ancoire en la chancelery de monseigneur de Flandres avant dit.) (f).

(8) Item, si demonstrent Jehan $f$. Wouters, Pietre Wouterszone son frere, Adrian Tant et Gille de ( $\mathrm{g}$ ) le Barse touz ensamble conioinctement, que, en 1 annee passee, en 1 une des sept neifs de Flandrez, qui adont furent prisez et menneez en Engleterre en venant de la Rochelle par les gentz du Roy, de la quelle neif fu maistrez le dit Pieter Wouterssone et contremaistre Chrestien Pieterssone, il eurent 8 tonnealx de vin de Poytou, li quel par les dis Engles furent gastez et en eurent li dit bourgoys de 1 Escluse la perte par 1 arest, que le dit Anglois en firent a Pleymue. En avoec ce si tollirent le dit Angloys az dis bourgoys le frait de 20 tonneaulx de vin, qui estoient a marchantz de France, pour cascun tonnel 60 escus de Bruges. Et ancoire leur fu tollu en ycelle neif, tant en apparaulx, comme en aultrez instruments et vitailles appartenanz a eaulx et a la dite neif, montanz la dite denraine perte a la somme de 16 livres d esterlincz.

(e) Bijgevoegd tussen de regels ter verbetering van ,approuvez", woord dat doorgehaald werd.

(f) Gans de klacht staat in de tekst doorgestreept. Zij was inderdaad reeds op de conferentie te Calais besproken geworden. Zie bijlage II, nr 16.

(g) In de tekst staat twee maal "de". 
(9) Item, se plaindent Henri Bast, le pere, et Jeorge de Rollerz, tant pour eaulx, comme leur compaingons flamencz, que, depuis un moys en cha, li Angloys de Zandwyc, assavoir est Symon Pavez et ses complicez, leur tollirent une cogue, chargie et affretee pour sigler a Bordeaulx, dont estoit maistrez Jan Willemssone de 1 Escluse, appelle la dite cogue Christofele, et dont lez 3 pars appartenoient az dis bourgoys et mananz de 1 Escluse. Et ancoire prirent li dit Anglois de la dite cogue, appartenantz a elle, un cent $\mathrm{d}$ aveine. Ancoire 1.000 de petit borz, appartenantz a la dite cogue. Ancoire si tollirent il au dit Henri Bast et Jehan Wayvliet 4 last de herencz sors et 2 last de herencz blancz, appartenantz a eaulx duex et a aultrui non. Ancoire prirent il hors de la dite cogue 5 last de blancz herencz et 2 last et demi de sors, appartenantz au dit bourgoys Jeorge de Rollerz. Ancoire y tollirent il 2 last de herencz sors, appartenantz a Pietre Colpaerd, bourgoys de la dite ville, et ancoire y tollirent il 200 garbez d aulx, appartenantz au dit maistre de la cogue, a Henri Bast et a Pietre Bronin, 1 un des maronnierz de la dite cogue, pour sigler, comme dist est, a Bordeaulx a toutez les dites marchandises, montanz la dite perte tout ensamble a la somme (h). Et est assavoir que la quarte part de la dite cogghe a touz les apparaulx d ycelle appartient a Jaquemon Hogheneuze, bourgois de la ville de Bruges.

(10) Item, si eut Jehanz Bruniel, Flamens et mananz a 1 Escluze, en la dite cogghe Christoffle 6 baris de herens sors pour envoyer a Bourdeaulx. Et est assavoir que le dit Symon si tient encorez en prison le dit Jehan Willems zone, maistre de la dite cogghe, en la chambre en Engleterre.

(11) Item, se demonstrent Henry Bast, que 1 anee passee 1 une des 7 neifs, dont mention est faite pardessus et dont maistre fu Clais Porre, se fu prinse a Fontenay et menee a Plainmue par forche des Engloys de Pleinmue. Assavoir est par un appielle le Crayere, qui maistrez estoit $\mathrm{d}$ une barge, en amenant de la Rochielle vins appartenanz a certains marchans de France, dont on doit encore au dit maistre payer a cause du dit affretement des dis vins. Assavoir est sire Phelippe de Cortenay 6 livres $\mathrm{d}$ estrelinx. Encore li doit li comtez d avanchier pour la dite cause 3 livres d estrelinx. Encore li doit Wayte Joye 20 s. d esterlinx. Encore li doivent cheulx de Plainmue 1 afraitement de cuincq tonniaulx de vin, de cescun tonniel 18 s. d esterlins (i). Et avoec ce tolirent il au dit maistre vitaille, apparaulx et armurez appartenans a la dite neif, montant tout ensamble, parmi 1 afraitement avantdit, 80 et 10 livrez d' estrelinx.

Supplyent tres humblement li dit plaingant pour eaulx et li bourchmaistre de la dite ville, ou nom de touz aultrez bourgoys et mananz d icelle

(h) Na ,somme" is er in de tekst weliswaar geen lacune, maar toch ontbreekt het cijfer van het bedrag in kwestie.

(i) "d esterlins" staat tussen de regels bijgeschreven ter verbetering van het woord "Inghelsche", dat in de tekst doorgehaald werd. 
ville, li quel aultre foys ont este, a toute leur supplicacions, ou qui ancoirez sont a venir, par devant notre redoubte seigneur, pour plaindre des Engles, a cause de luer perte, qu il en ont eu et soustenu, liquel presentement ne poent venir par devant lez dis seigneurs pour faire leur requestz, pourtant qu il ne somt (j) point par aventure ou pays ou si pres de chi pour demonstrer luer querelle a notre dit redoubte seigneur et les seigneurs de son noble conseil, que a ses dis subges, sur ce que dit est, soit pourveu de remede convenable et prise aucune voye faisable, par quoi dorez en avant ses diz subges, marchantz, maistres et maronnierz plus paisiblement puissent passer par mer entre les Engles en la maniere que bon luer samblera ou aultrement il est a doubter que ses dites genz perderont toute luerz neifs et marchandises, toutes par tamps advenir, que dieux voille deffendre. En en che tant a faire, qu il soient tenu de plus pryer pour lui.

(j) Sic voor ,sont”.

\section{IV}

Antwoord van de leden van de grafelifke rad, gegeven aan de commissarissen van de koning van Engeland op de conferentie van 26 mei 1379 te Brugge, inzake de door de Engelsen tijdens de besprekingen van 10 juli van voorgaand jaar te Calais ingediende klachten.

\section{Brugge, 26 mei 1379 \\ Rijsel, Archives départementales du Nord, B 515 / 18.778bis. Op papier.}

De klachten laten we door een nummering voorafgaan.

Ce sont les responses dou consel monseigneur de Flandres, assavoir est le doien Saint Donas de Bruges, messire Jehan Vilain, le prevost de Notre Dame, Jehan de la Faucille, et Guillaume de Haringhes, clerc secretaire dou dit monseigneur de Flandres, commissaires en certe partie ou nom et de par mon dit seingneur, faites et baillies as commissaires dou Roy d Engleterre, est assavoir sire Guillaume de Gantdorp, Esmon de Halstede et Richard Woedehalle, au traitie, tenu a Bruges le 26. jour de may 1 an 1379 , sur les complaintes des subges dou dit Roy, baillies oultre a la journee dou traitie tenu a Calais parentre les commissaires des dis seingneurs, le 10 e jour de jullet 1 an 78, d aucuns griefs et domages, fais sur mer par les subges $\mathrm{d}$ un coste et $\mathrm{d}$ autre, ainsi qu il est contenu en 1 rolle, plaquie de leurs seels sur ce fait.

(1) Premiers, quant a la complainte de Jehan Edrop, vivetier de Londres, et autres marchans d Engleterre, ses complices, de Guy Cuidiel, maronnier de 1 Escluse etc. Respondent le consel de Flandres par la maniere, qui 1 est contenu en la response que Jaqueme Crakebeen, bourgois de Bruges, pour lui et ses compaignons a bailliet oultre sur ce au dit consel, ainsi qu il appert par la copie annexee ci desoubs. 
(2) Item, quant a la complainte de Thomas Sir, marchant de Bristauwe, $d$ un maistre maronnier de 1 Escluse etc. Respondent le dit consel par la maniere, qui 1 est contenu en la response, que Pieter le Stocker, maronnier de 1 Escluse, a bailliet oultre sur ce au dit consel, ainsi qu il appert par la copie annexee ci desoubs.

(3) Item, quant a la complainte de Robert Blount et Symon Wilhmet, comment deus nefs de Flandres prirent et roberent sur mer une neif chargie de poisson etc. Respondent le dit consel que sur le dite complainte il ont prise et faite information a Oostende et ont sur ce oy plusieurs tesmoings, bonnes gens, dignes de foy, tant d Oostende, comme d ailleurs, maronniers et autres, et bien et diligaument examines par leur serment, et $\mathrm{n}$ on point trouve par la dite information que le fait, dont la complainte fait mention, ait este fait par aucuns d Oostende, ne aussi que aucun des mariniers d Oostende portast 1 rouge drap en son voille, ainsi que la complainte fait mention.

(4) Item, quant a la complainte de Nicolas Brembre et Jehan Philipot, marchans de Londres, sur Wauter Janszone, maronnier de 1 Escluse etc. Respondent le dit consel par la maniere, qui 1 est contenu en la response, que Jehan Belle de 1 Escluse a bailliet oultre sur ce audit consel, ainsi qu il appert par la copie ci desoubs annexee.

(5) Item, quant a la complainte de Robert Pilche, Richart Flete et Jehan Horeweder, seingneurs $d$ une barge de Ploumith, sur Mathis $f$ Clais etc. Respondent le dit consel par la maniere qu il est contenu en la response, que le dit Mathis a bailliet oultre sur ce audit consel, ainsi qu il appert par la copie ci desoubs annexee.

(6) Item, quant a la complainte de Thomas Gendalier, citain de Londres, sur le bailliu de 1 eauwe, de ce que le dit bailliu arresta au dehors dou havene de 1 Escluse 85 dousaines de divers draps etc. Respondent le consel que ceste complainte touche et regarde le droit et seignorie de monsegneur et en sera fait aussi avant, comme il a este dit et respondu au consel d Engleterre.

Notandum, que sur le complainte des dis draps fu respondu par le consel de Flandres au consel d Engleterre parmi les deputes des bonnes villes, que selon 1 anchienne costume maintenue ou pays de Flandres, les dis draps sont confisquiet a monseigneur de Flandres de son droit et seingorie. Nientmains ou cas que le consel d Engleterre respondent bien et raisonnablement sur les complaintes des subgis de monseigneur et fachent bon adrechement et restitution a euls de leur domages, tellement que par raison il doie souffire et le Roy d Engleterre en voelle escrire a monseigneur de Flandres, ainsi qu il a fait autreffois en cas samblable, le consel de Flandres esperre que monseigneur de Flandres pour 1 oraire (a) et

(a) Onzekere lezing. Er staat geschreven met een afkortingsteken : „1 orai-e”. Aangezien daarop volgt „et pryere", kunnen we hier met synoniemen te doen hebben. Misschien werd dus met het eerste woord zoveel als „oraison" bedoeld. 
pryere dou Roy en fera tant, qu il en sera bien content, par ainsi que le marchans, a qui les draps appartenoient, vienge par decha pour dire combien les draps pooient valoir et traiter a lui et on lui fera tant qu il devra souffire.

\section{V}

Verweerschrift, warin Jaque Crakebeen, burger van Brugge, en zijn geassocicerden, in antwoord op de eisen van een Engelse koopman, bun opdrachigever, an de grafelijke ratd uiteenzetten, boe bun schip, terugkerend van Bordeaux, op zee door Normandische kapers genomen geworden was, wadrdoor zij ook de vracht verloren, wat voor ben een verlies van 1.800 frank betekende, som die zij niet bebben kunnen recupereren, niettegenstaande een brief verkregen van de Franse koning en gericht tot de Normandiërs en ondanks de beslaglegging door bun schipper op twee vadrtuigen met Normandische goederen, die naar Engeland gebracht werden, zijnde allemal feiten gekend door de Engelse klagers, die wel weten dat dit alles maar een gevolg is van de oorlog, die de Engelsen tegen de Fransen voeren.

Tussen 10 juli en 25 november 1378

Rijsel, Archives départementales du Nord, B 515 / 18.778 bis, gelijktijdige kopie op papier.

Sur la demande que Jehans Edereep de Londrez demande a Jaque Crakebeen et ses compaignons pour restitution de ses biens, qui estoient quierquies en la neif, que Ghijs Cudel soloit menner, la quelle fu prinse des Normans, environ un an, a venant de Bordeaux, viers Engleterre et fu droit devant Beauchief. Si respondent le dit Jaque et si compaignons que de nulle restitution il ne sont tenu au dit complaignant, car la dite neif a este prince pour le guerre des Engles et des Franchois et pour les biens d Engleterre, qui dedenx la neif estoient, et non pour aultre cause. Et si ont perdu li dit Jaqueme et li sien, pour la dite cause des Engles, luer dite neif et quanques ens y avoient, qui bien valoit 1.800 frans, par mi le frait, dont onques ne puerent recouvrer pour poursieute aucune, qu il en firent, ne pour mandement, ne lettrez du Roy, que li Roy luer donna as dis Normans, que bien encore pueent monstrer, une suele maille, ainssi que clairement asses appert, car par deffaute, qu il en ont eu, li dis Ghys Kudel a depuis prins 2 neifs, une de Normandie et une de Flandres, quierquies de biens de Normans, et les ammena en Engleterre, la il sont encore, pour recouvrer son proppre dammage et ce seit bien li ditz complaignantz, car il detiennent a present en Engleterre le dit Ghys emprisonnes. Et $s$ il fuist raisonnable puis que la neif a este perdue pour la cause et ocoison des Engles, li dit Flamenc requerroient volentiers a recouvrer sour eaux luer dit dammage. 
Brief uitgaande van Karel $V$, koning van Frankrijk, en gericbt tot diens vertegenwoordiger of familielid in Normandië, met bet verzoek de kogge, geladen met wijn en toebeborend aan Jaques Crakebeen en Pieter Crooc, burgers van Brugge, die, van Bordeaux terugkerend en op weg zijnde naar Engeland, de maand voordien, op zee door kapers van Saint-Valéry genomen was geworden, met haar lading aan de schipper en de meevarende kooplui terug te geven en dit zonder enig verzet, aangezien de Bruggelingen die gunst verkregen badden.

Senlis, 7 april (1378)

Rijsel, Arcbives départementales du Nord, B $515 / 18.778$ bis. Op papier. Waarschijnlijk gelijktijdige kopie.

De par le Roy.

Tres chier et ame cousin. Comme nous avons entendu que une coque, qui est a Jaques Crakebeen et Piere Crooc, bourgois de Bruges, les quels sont nous biens voullans, et de la quele estoit gouverneur un apelle Guis Cudel, soit partie de 1 Escluse en Flandres et alee en Geronde. Et ait este chargie a Bourdeux de vins. Et en retournant pour aler en Engleterre, un mois a ou environ, ait este prinse de chuinc barges de Saint Walery, dont les mestres ont nom Virlet Stasse, Hughe Capelaire, Jehan Coput et plusieurs autres leurs compaingnons. Nous volons et vous mandons que la dite coque aveuque les apparans et le fret fait entre les maistre et les marchans, qui estoyent dessus, vous rendes et delivres ou faites rendre et delivrer au dyt Jaque, Piere et gouverneur sans contredyt. Car ainsi 1 avons otroye aus diz bourgois de Bruges de nostre deliberalite et grace. Bien gardes que en ce $n$ ait deffaut. Donne a Senliz le $7 e$ jour d avril.

\section{VII}

Verweerschrift, wadrin Pieter Stoker, schipper uit Sluis, in antwoord op de antijgingen van Engelse kooplui, zijn opdrachtgevers, aan de graaf uiteenzet, boe bij met zijn schip, de "Heilige Geest", van Spanje terug. kerend met een lading wijn en op weg nadr Londen, op zee nabij Sandwich door kapers uit Calais beroofd geworden was en boe bij daarna, vluchtend voor Normandische zeerovers en voor een grote storm, in de Zwinhaven een toevlucht had moeten zoeken, met als gevolg dat zijn geschil met de Engelsen weliswaar te Damme voor de schepenbank gerechtelijk beslecht geworden was, maar zonder met de door hem geleden schade rekening te bouden, reden warrom bij om schadeloosstelling verzoekt.

Tussen 10 juli en 25 november 1378

Rijsel, Archives départementales du Nord, B515/18.778 bis. Gelijktijdige kopie op papier. 
Tres cher seigneur, plaise vous savoir que comme Pieter Stokel, maronnier de 1 Escluse et maistre d une neif appelle Saint Esprit de 1 Escluse, venant son droit chemin d Espaigne vers Londres et droit devant le port de Zandwyc vinrent barges de Calais et prinrent la dite nef et 1 ammenerent, a tout les biens estans en ycelle, devant Calais, dont les maistres des dites barges sont appelles Jaque Pieters Moer et Obbe Ghibbe, par forche, et maugre dou dit maistre, non provoquant, as dits Englois fu monstre, que la dite neif et marchandise estoit affreite a Londres et que marchans anglois estoient en la dite neif pour les biens garder, a qui les dis biens appartenoient, prinrent hors de la dite neif 24 tonneaux de viin, toutes les armures et vitaille, ancres, cables, coquet et batel et la dite neif, estans devant le port de Calais, vinrent des barges de Normendie et grant orage de mer et, pour le sauvement des biens des marchans, le dit maistre vint a toute sa dite neif et marchandise, estans en ycelle, tout droit ou port de 1 Escluse, dou quel debat entre le dit maistre et marchans englois, a qui les dis biens appartenoient, a este faite loy en la ville dou Dam, u sieur Pieter Scotelaere fu present, mais son dammage, que li dis maistre avoit eu pour cause des Anglois, ne li fu onques amende, li quel monte bien $50 \mathrm{lb}$. de gros et plus. Supplie a vous tres humblement, qu il vous plaise de lui prendre pit(i)e et en ce tant faire que au dit maistre soit restitution faite de son dit dommage, ainsi avant comme a votre discretion de raison samblera.

\section{VIII}

Verslag van het onderzoek door de grafelijke commissarissen te Oostende naar aanleiding van een klacbt als zouden Vlaamse zeelui op zee een Engels vaartuig uit Southam bebben angevallen en beroofd en de bemanning ervan, tellende twalf koppen, bebben vermoord.

Oostende, 3 december 1378

Rijsel, Archives départemeniales du Nord, B1376/10.694(2). Op papier.

Information faite a Oostende le 3. jour de decembre 1 an 78 par monseigneur le prevost de Notre Dame de Bruges, messire Jehan Vilain, et Jehan de la Faucille, commissaires de par monseigneur de Flandres, sur une requeste et complainte, que aucuns d Engleterre ont bailliet oultre a la journee tenue a Calais ou mois de jullet derrain passe, de ce que aucuns maronniers d Oostende prirent et roberent une neif chargie de poisson, appartenant a Symon Willymet de Sueteham et ses compaingons, et tuerent 12 personnes estans en ycelle.

Premiers, Clais le Stuvere, maronnier et eschevin d Oostende, $46 \mathrm{~d}$ eage ou environ, dist par son serment sur ce diligament requis, qu il $\mathrm{n}$ a point sceu ne oy que par aucuns mariniers $d$ Oostende aucune prise ou domage fust fait sur les Engles ou temps que la complainte fait mention. Mais bien dist que il a bien sceu que 1 maistre maronnier de Hughevliete, appielle 
Pieter Arents zone, portant ou voile de sa neif 1 rouge drap de long, prist aucun poisson hors d une neif d Engleterre ou dit temps, dont il fu calengies de la justice dou lieu de Dunkerke. Et de la nef, qui devoit estre prise, et des 12 personnes, qui y furent tues, si comme les Engles dient, n en scet riens.

Jehan le Fevre, borchmaistre

Henry fil Wauter

Gherard Sabbaert

Clais Juerdaen

Eschevins d Oostende,

$\mathrm{n}$ en scevent riens.

Wauter Hackart, eschevin d Oostende, dist par son serment, qu il vit sigler devant Oostende une neif qui portoit en son voile 1 rouge drap et disoit on que la neif estoit de Hughevliete et fu en ce mesme temps que la complainte contient ou environ et autre chose $n$ en scet.

$\left.\begin{array}{l}\text { Henry Riquards zone } \\ \text { Willame fil Jehan fil Gille } \\ \text { Lauwerens le Boetere }\end{array}\right\} \begin{aligned} & \text { Eschevins de Blankenberghe, } \\ & n \text { en scevent riens. }\end{aligned}$

Willame le Schuvere, del eage de 60 ans

Riquard f.Jehan, del eage 50 ans

Girard Schelewart, del age 45 ans

Lambert Libart, de 40 ans d eage

Guillaume Motin

Guillaume Kersteloot, del age de 60 ans

$\mathrm{n}$ en scevent riens.

Wauter fil Jan Heinrix d Oostende, del age de 47 ans, dist par son serment, qu il vit que Pieter Arents zone, maronnier de Hughevliete, portoit ou voile de sa neif 1 rouge drap en ce meisme temps et autre chose $\mathrm{n}$ en scet riens.

Jehan But d Oostende, del eage de 48 ans, dist de mot a mot, ainsi que Wauter fil Jehan, tesmoing dessus oy, a dit.

Jaqueme Raimbouds d Oostende, del eage de 48 ans ou environ, dist par son serment, qu il sigla vers la costiere d Escoche en la compaingie de Pieter Arents zone de Hughevliete, le quel portoit ou voille de sa neif 1 rouge drap. Mais des autres choses n en scet riens et fu 15 jours apres Pasques ou environ darrain passe.

Pieter Steve d Oostende, del eage de 50 ans ou environ, dist par son serment, qu il fu a Dunkerke 1 peu devant la Penthecouste derrain passe, ou il vit Pieter Arents zone, qui portoit en son voile 1 rouge drap, vendre certaine quantite de poisson, qu il avoit meisme pris, et autre chose n en scet. 
Jehan Gorlin

Roelin fil Jehan

Jehan Bone

Coppin Lammins

Jehan Bigghe

Jehan Willems

Lauwers Hughe

Reynar Romains

Jan Tand tous maronniers d Oostende, dient par

leur serment $\mathrm{qu}$ il $\mathrm{n}$ en scevent riens

IX

Verweerscbrift, warin Jeban Belle, burger van Sluis, als antwoord op de beschuldigingen geuit door Engelse kooplui, zijn geassocieerden, aan de grafelijke rad verzekert zijn verplichtingen in de associatie te zijn nagekomen en verklaart, dat bij er geen schuld aan beeft, indien Wouter Janssone, die bij als schipper angesteld had, het schip met de vracht wol, die naar Calais moest worden gebracht, ontureemd beeft om de lading in Normandië te verkopen.

\section{Tussen 10 juli en 25 november 1378}

Rijsel, Archives départementales du Nord, B515/18.778 bis. Gelijk. tijdige kopie op perkament. De rechter kant van het stuk is beschadigd.

A nobles et sages les seigneurs du conseil de mon tres redoubte seigneur de Flandres.

Monstre Jehan Belle, bourgoys del Escluse, comme celui qui a entendu que certainez parsonnez, noumez par leurs noms Nicholais Brambourch et Jehan Philippot, marchanz de Londrez, dient et monstrent qu ils chargirent et delivrerent au moys de fevrier derrain passe a Wouter Janssone, maronnier del Escluse, jusques a noef scarpellyes de laynez, les quelles laynes il devoit avoir admene a 1 estaple de Callays, le quel Wouter Janssone arriva a Dunkerke avoec tous les dites lainez a sauvete. Et depuis s emparti de la par son bon gre et admena les dites lainez en Normandye et la en feist delivrance et les vendi a dampmage des dis marchanz, de quatre centz et ciuncquante marz estrelincz et que il feist mesme le dit Wouter Janssone maistre de la neif, en la quelle lez dites lainez estoient chargies, et que il estoit sirez de la dite neif ou avoit partye d icelle.

Sur quelle demande le dit Jehan Belle respond que ou temps que la dite neif fu chargie a 1 Escluse des bienz des marchans, qui 1 avoient freste, il gisoit sur son lit malades et $\mathrm{n}$ estoit point si posant ne si fort de soy mesmez qu il povoit gouverner la dite neif. Et selonc qu il fu enforme en feist maistre le dit Janssone, car adont ne savoit en lui que $\mathrm{d}$ un boin loyal homme et de bonne renommee, ainsi comme il quidoit et enformez estoit.

Item, monstre le dit Jehan Belle que le dit Wouter Janssone, maistre comme dit est, s en departi a toute la dite neif du able del Escluse et accomplist le voiage jusques a Londrez et la commencha il a juer a des, si 
avant qu il y perdi chiunc noblez, les quels le dit Nicholais Brambourch, qui avoit et a lui appartenoit la moitie de la dite neif, paia pour lui et aultrez chiunc lui en presta pour appareiller la dite neif. Et par consequent povoient les dis marchants mieulx savoir que le dit Jehan Belle, que le dit Wouter Janssone estoit personne de male condicion. Et quant les dites lainez furent chargies a Londrez, Jehan Belle $\mathrm{n}$ en savoit riens, ne aussi riens $\mathrm{n}$ en a este fait par lui. Et aussi voelt il faire serment et preuve, selon que bonne personne doit et est tenus a faire, qu il $\mathrm{n}$ avoit onques pourffit, part, maille, ne denier des dites lainez, ne de la dite neif et biens d ycelle du tamps qu il aient este en gouvernement du dit Wouter Janssone.

Item, monstre le dit Jehan Belle que tout le droit et tout la part du gaing, que le dit Nicholay Brambourch doit et est tenuz a avoir et rechevoir dou gaing (dans)(a)la moitiet de sa neif, dont Jehan Belle en a 1 aultre moitiet, et de tous affretements ou aultrement jusquez aujour duy, que il a ce paijet et donnet par especial mand(ement au) dit Nicholai par sa bouche a Thomas Baret et a Thommelin Brom, factuers et attournez dou dit Nicholai, a plusieurs foys et en plusieurs lieus lez quels ce ont... (b) ou nom et pour le dit Nicholai Brambourch. La quelle response et chose le dis Jehan Belle offre et presente a faire et approuver par bonnez gens digne de foy. Et...le dit Jehan Belle supplye humblement a vouz, tres noblez seigneurs, qu il vous plaise tant a faire par quoy le dit Nicholai laist le dit Jehan en pays et sanz... (c).

(a) Wegens beschadiging kunnen de laatste regels niet volledig gelezen worden.

Tussen haakjes staat de veronderstelde tekst.

(b) Aan te vullen wellicht met, ,respondu".

(c) Misschien aan te vullen met "destourbier".

\section{$\mathrm{X}$}

Verweerschrift, wadrin Mattbys Claissone, kapitein van de westvloot van Vlaanderen, en zijn gezellen, als antwoord op een Engelse aanklacht, aan de grafelijke raad uiteenzetten, boe zij in bet voorjaar van 1378, bij de terugkeer van de eerste westvloot, van de gelegenheid gebruik maakten om van Engelse kapers uit Plymouth en Dartmouth, die met de bemanning van een Spaans schip aan het strijden waren, een geroofd Vlaams vaartuig afhandig te maken, reden wadrom ze overigens beden te La Rocbelle eveneens gewikkeld zijn in een geding met de Spanjaarden, die eveneens op die buit aanspraak maken en als schadeloosstelling 4.000 frank eisen.

Tussen 10 juli en 25 november 1378

Rijsel, Archives départementales du Nord, B515/18778 bis. Gelijktijdige kopie op perkament. 
Tres nobles et reverends signeurs du conseilg notre redoubte signeur, monsigneur le conte de Flandres, a vous monstrent vos humbles subgis Matthys $\mathrm{f}$. Clais, capitain de le flote ou tamps passe de notre redoubte signeur susdit, et ses compaignons, comment qu il ont entendu que cheaus de Pleymude et de Terremude sour eaux ont mis une demande et plainte, fait devant vous, redoubte signeurs, que li capitain et ses compaignons dessus dit avoec le premiere flote venant de west, ordene de par monsigneur dessus dit et du paijs communaument de Flandres, a eauls devoient avoir pris une neif d Espaigne avoecques le avoir et les appartenances, qui dedens y estoient, et a eauls une aultre neif robeye et prise, du quel il en ont nulle coupe, ne ne firent onques, ainsi comme, tres redoubte signeurs, vous chi bien apres entendres.

Bien fu voir que cheaus de Pleymude et de Terremude susdit venoient sur le mer en le flote monsigneur de Flandres susdit sans mot parler avoec un huelc d Engleterre et un crayere de Flandres, le quelle neif appelle crayere il avoient pris as Flamens et les gens, qui y estoient dedens, hors cachies, le quelle neif appartenoit a aucuns bourgois de Bruges, c est assavoir a Jehan de Tournay et a son frere, et seinglerent avoecques ces dessus dites neifs une neif de le flote de Flandres une grande pieche du castel de le dite neif, de le quelle maistre estoit Guillaume Beits del Escluse, et $y$ trayerent sur eauls avoec leur arcs. Et apres seinglerent il a une neif d Espaigne gisant d encoste le dite flote de Flandres et le combatirent 1 un a 1 aultre, du quel le dit capitain et ses compaignons ne se mellerent onques. Le quel Espaingart si se revaigna, que le neif d Engleterre convenoit de partir du dit Espaignard et eaux laissier en pais et waigna la dite neif flamenghe, le quel les dis Engles y avoient enmeneye. Et quant che le dit capitain et ses compaignons virent, se alerent vir en luer petits bakes, de quel lieu le dite neif estoit venue et ni trouverent nulle personne dedens vivant, que deux gents d Engleterre et un d Almaigne, les quels il prisrent as dits Espaignaerds pour luer vie sauver. Et si il y eurent plus dedens trouve, il y eurent plus pris pour leur vie sauver. Et luer demanderent de quel lieu le dite neif luer venoit et ou il le avoient prise et il responderent qu il le avoient pris sur le meir et les gents, qui dedens estoient, estoient ent ales avoec les petyts bakes. Et quant le dit capitain ce entendi, ala as ses compaignons et avoec eauls au dit Espaignard et li prisrent le neif par mi che qu elle fu de Flandres. Et quant li dit Espaignard vit che que le neif dessus dite luer devoit demorer, les mist a loy quant il vinrent a le Rochele et luer demanda quatre mille frans, pour che qu il avoient pris luer prisonniers et le dite neif, le quel encore y est a loy. Et les amis du capitain luer a bien laissiet savoir de vray, qu il luer convera paijer. Et tres noble et reverend signeur, si che fu que cheaus de Pleymude et de Terremude susdit dient aucune contraire les choses ne furent ainsi comme devant est dit en tout ou en partie, che presentent le dit capitain et ses compaignons plainement et souffisaument de vous ent informer. Supplient a vous, tres noble et reverent signeurs, comme vos humble subgis et tant humblement de cuer, comme il poont, qu il vous plaise de che eaulx tenir en droit comme vos petits servants et subgis. 